\title{
Detrimental Effect of Sintering Additives on Conducting Ceramics: Yttrium - Doped Barium Zirconate
}

\section{$\operatorname{AUTHOR}(\mathrm{S}):$}

Han, Donglin; Uemura, Shigeaki; Hiraiwa, Chihiro; Majima, Masatoshi; Uda, Tetsuya

\section{CITATION:}

Han, Donglin ...[et al]. Detrimental Effect of Sintering Additives on Conducting Ceramics: Yttrium - Doped Barium Zirconate. ChemSusChem 2018, 11(23): 4102-4113

\section{ISSUE DATE:}

2018-12-11

URL:

http://hdl.handle.net/2433/236387

\section{RIGHT:}

This is the peer reviewed version of the following article: ChemSusChem 2018,11,4102 - 4113, which has been published in final form at https://doi.org/10.1002/cssc.201801837. This article may be used for non-commercial purposes in accordance with Wiley Terms and Conditions for Use of Self-Archived Versions.; The full-text file will be made open to the public on 11 December 2019 in accordance with publisher's 'Terms and Conditions for SelfArchiving'.; This is not the published version. Please cite only the published version.; この論文は出版社版でありません 


\section{Detrimental Effect of Sintering Additives on Conducting Ceramics: Yttrium-Doped Barium}

\section{Zirconate}

Donglin Han ${ }^{\text {a* }}$, Shigeaki Uemura ${ }^{\text {b }}$, Chihiro Hiraiwa ${ }^{\text {b }}$, Masatoshi Majima ${ }^{\text {b }}$, Tetsuya Uda ${ }^{\text {a* }}$

${ }^{a}$ Department of Materials Science and Engineering, Kyoto University,

Yoshida Honmachi, Sakyo-ku, Kyoto 606-8501, Japan

b Sumitomo Electric Industries, Ltd.,

1-1-1, Koyakita, Itami-shi, Hyogo 664-0016, Japan

* Corresponding authors: Donglin Han (han.donglin.8n@kyoto-u.ac.jp)

and Tetsuya Uda (uda_lab@aqua.mtl.kyoto-u.ac.jp)

TEL: +81-75-753-5445, FAX: +81-75-753-5284 


\section{Abstract}

Y-doped $\mathrm{BaZrO}_{3}(\mathrm{BZY})$ is currently the most promising proton conductive ceramic-type electrolyte, showing perspective application in electrochemical devices, including fuel cells, electrolyzer cells. However, due to its refractory nature, sintering additives, such as $\mathrm{NiO}, \mathrm{CuO}$ or $\mathrm{ZnO}$ was commonly added to reduce its high sintering temperature from $1600{ }^{\circ} \mathrm{C}$ to around $1400{ }^{\circ} \mathrm{C}$. And even without deliberately adding the sintering additive, the $\mathrm{NiO}$ anode substrate provides another source of the sintering additive; that is, during the co-sintering process, NiO diffuses from the anode into the BZY electrolyte layer. In this work, we conducted a systematic work to study the effect of $\mathrm{NiO}, \mathrm{CuO}$ and $\mathrm{ZnO}$ on the electroconductive properties of $\mathrm{BaZr}_{0.8} \mathrm{Y}_{0.2} \mathrm{O}_{3-\delta}$ (BZY20). The results revealed that adding $\mathrm{NiO}$, $\mathrm{CuO}$ or $\mathrm{ZnO}$ into BZY20, not only degraded the electrical conductivity, but also resulted in enhancement of the hole conduction. Exclusion of these added sintering additives can be realized by post-annealing in hydrogen at the mild temperature of $700{ }^{\circ} \mathrm{C}$, but kinetically very slow. So, it can be concluded that adding $\mathrm{NiO}, \mathrm{CuO}$ and $\mathrm{ZnO}$ is detrimental to the electroconductive properties of BZY20, and greatly restricts its application as an electrolyte. Developing some new sintering additives, new anode catalysts or new methods for preparing the BZY electrolyte-based cells appears to be urgent. 


\section{Introduction}

Solid oxide fuel cells (SOFCs) using oxide ion-conductive ceramic-type electrolyte, e.g., yttriumstabilized zirconia (YSZ), possess the highest energy conversion efficiency among various types of fuel cells, but the high operation temperature (typically, $>800^{\circ} \mathrm{C}$ ) results in great obstacle against their popularization. Replacing the electrolytes in SOFCs with the proton-conductive types appears to be a promising strategy to reduce the operation temperature [2], since the conduction of protons has relatively lower activation energy than that of the oxide ion conduction, sufficient proton conductivity can be thereby achieved at intermediate temperature range $\left(400-700{ }^{\circ} \mathrm{C}\right)$.

Currently, 20 mol\% Y-doped $\mathrm{BaZrO}_{3}\left(\mathrm{BaZr}_{0.8} \mathrm{Y}_{0.2} \mathrm{O}_{3-\delta}\right.$, BZY20) attracts the most attention [3-6], due to its high proton conductivity (e.g., $>0.01 \mathrm{Scm}^{-1}$ at $450{ }^{\circ} \mathrm{C}$ [7]), almost pure proton conduction in humid hydrogen atmosphere [8], and excellent chemical stability against reaction with $\mathrm{CO}_{2}[9,10]$. However, the refractory nature of BZY20 requires quite high sintering temperature (at least $1600{ }^{\circ} \mathrm{C}$ ), leading to significant challenge on its implementation in the fuel cells [11]. Adding sintering additives, such as $\mathrm{NiO}[12-14], \mathrm{CuO}[14,15]$, or $\mathrm{ZnO}[11,16-18]$, can reduce the sintering temperature effectively to around $1400{ }^{\circ} \mathrm{C}$, and is already widely adopted to process BZY20. But, it is worth to note that even without deliberatively introducing sintering additive, $\mathrm{NiO}$ in the anode substrate (lately in-situ reduced to Ni anode catalyst) provides another source of sintering additive. As a preliminary examination, we prepared an anode-supported half cell, which has the most common cell configuration composed of a thick BZY20 - $60 \mathrm{wt} \% \mathrm{NiO}$ anode substrate and a thin BZY20 electrolyte (without 
adding any sintering additive) deposited by spin-coating. After co-sintering at $1500{ }^{\circ} \mathrm{C}$ in oxygen for $10 \mathrm{~h}$, the white electrolyte layer turned to be black (Fig. 1(a)). Further analysis on cross-section area (Fig. 1(b)) confirms the existence of around 1 at\% $\mathrm{Ni}$ in the entire dense electrolyte (Fig. 1(c)), indicating that the co-sintering process drove $\mathrm{NiO}$ to diffuse into the electrolyte layer. In spite of the recent report by Duan, et al., [19], which demonstrated a high performance fuel cell using the BZY20 electrolyte added deliberately with $1 \mathrm{wt} \% \mathrm{NiO}$, which showed conductivity remarkably close to 0.01 $\mathrm{Scm}^{-1}$ at $600{ }^{\circ} \mathrm{C}$, in most cases, as summarized in Table 1, the conductivity of the electrolyte in the cosintered cells decreased significantly to the range of $0.001-0.003 \mathrm{Scm}^{-1}$. And the open circuit voltage (OCV) at $600{ }^{\circ} \mathrm{C}$ is typically around $0.99 \mathrm{~V}$, obviously lower than the theoretical value about $1.14 \mathrm{~V}$ (calculation condition: $\mathrm{H}_{2}-5 \% \mathrm{H}_{2} \mathrm{O}$ for anode, and $\mathrm{O}_{2}-5 \mathrm{H}_{2} \mathrm{O}$ for cathode). But, such loss in OCV was usually simply attributed to an unsuccessful gas sealing.

Decreasing the sintering temperature by adding $\mathrm{NiO}, \mathrm{CuO}$, or $\mathrm{ZnO}$, and co-sintering the $\mathrm{NiO}$ anode supported cells are currently the mainstream method to prepare BZY electrolyte-based fuel cells. Although some reports have shown the degradation in electrical conductivity by adding ZnO [11, 1618] or $\mathrm{NiO}$ [33-35], the community still shows insufficient concern on the negative effect on electrical properties by adding these sintering additives. Especially, as far as we know, there is no report on the effect on the transport properties of BZY20 by adding these oxides, which is another very vital factor restricting the fuel cell performance [36]. Furthermore, a couple of very important information is lack, such as the effect of adding sintering additives on the proton concentration and chemical 
expansion of BZY20, which are related to science of the transport properties of BZY and important information for implementing BZY20 electrolyte into the electrochemical devices. And still, it remains as an open question that whether these sintering additives can be removed by post-annealing in reducing atmosphere at moderate temperature. In this work, based on a systematic investigation on three representative sintering additives for BZY20, namely, $\mathrm{NiO}, \mathrm{CuO}$ and $\mathrm{ZnO}$, we want to emphasise that concern should not be solely placed on their ability to improve the sinterability of BZY20, the negative influence on a couple of fundamental properties of BZY20 should also be considered seriously.

\section{Experimental}

\subsection{Material Preparation}

$\mathrm{BaZr}_{0.8} \mathrm{Y}_{0.2} \mathrm{O}_{3-\delta}$ was prepared by a conventional solid state reaction method. Starting materials of $\mathrm{BaCO}_{3}$ (Wako Pure Chemical Industries, Ltd., 99.9\%), $\mathrm{ZrO}_{2}$ (Tosoh Corporation, 98.01\%), and $\mathrm{Y}_{2} \mathrm{O}_{3}$ (Shin-Etsu Chemical Co., Ltd., 99.9\%) were mixed at the desired ratio, and ball-milled for $24 \mathrm{~h} . \quad$ After being pelletized under $9.8 \mathrm{MPa}$, the sample was heat-treated at $1000{ }^{\circ} \mathrm{C}$ for $10 \mathrm{~h}$. Then, the sample was pulverized and ball-milled for $10 \mathrm{~h}$, and pelletized under $9.8 \mathrm{MPa}$ again, with a subsequent heattreatment at $1300{ }^{\circ} \mathrm{C}$ for $10 \mathrm{~h}$ for synthesizing. After being pulverized and ball-milled for $100 \mathrm{~h}$, the obtained BZY20 powder was mixed with 0.2, 0.5, 1 or 2 wt\% NiO (Nikko Rica Corporation, 99.9\%), CuO (Nacalai Tesque Inc., 99.9\%) or ZnO (Wako Pure Chemical Industries, Ltd., 99.9\%), and 
subjected to ball-milling for $10 \mathrm{~h}$. The mixture was then pressed at $392 \mathrm{MPa}$ into pellets with thickness and diameter around $1 \mathrm{~mm}$ and $11 \mathrm{~mm}$, respectively. After being embedded in BZY20 sacrificial powder, the samples were heat-treated at $1500{ }^{\circ} \mathrm{C}$ for $10 \mathrm{~h}$ in oxygen atmosphere for sintering. For comparison, the pure BZY20 powder was also pelletized, embedded in BZY20 - 1 wt\% $\mathrm{BaCO}_{3}$ sacrificial powder, and subjected to sintering performed at $1600{ }^{\circ} \mathrm{C}$ for $24 \mathrm{~h}$ in oxygen atmosphere.

\subsection{Characterization}

Chemical compositions were determined by inductively coupled plasma atomic emission spectroscopy (ICP-AES) with SPS4000 (Seiko Instruments Inc., Chiba, Japan). Microstructures were observed by electron probe microanalyzer (EPMA) with JXA-8530F (JEOL, Tokyo, Japan) and scanning transmission electron microscopy (STEM) with JEOL JEM-2100F. Wavelength-dispersive X-ray spectroscopy (EPMA-WDS) and energy dispersion X-ray spectroscopy (STEM-EDS, JEOL JED2300) point analysis was applied to determine the local composition. Samples for STEM observations were thinned by an argon ion $\left(\mathrm{Ar}^{+}\right)$beam using a JEOL EM-09100IS Ion Slicer.

Powder X-ray diffraction (XRD) measurements were performed using $\mathrm{Cu} K \alpha$ radiation with X'Pert PRO MPD (PANalytical, Almelo, Netherland). High temperature XRD (HT-XRD) measurements were performed using a HTK 1200N high-temperature chamber (Anton Paar, Graz, Austria) attached to the PANalytical X'Pert PRO MPD diffractometer. Dry or wet ( $\left.p_{\mathrm{H}_{2} \mathrm{O}}=0.031 \mathrm{~atm}\right)$ argon gas was 
fed through the high-temperature chamber. HT-XRD patterns were collected during cooling from 1000 to $30{ }^{\circ} \mathrm{C}$ at an average cooling rate about $1.06{ }^{\circ} \mathrm{Cmin}^{-1}$. Detailed procedures of HT-XRD measurements were described in our previous work. [37, 38] Rietveld refinement was carried out utilizing a commercial software X'Pert HighScore Plus to determine lattice constants.

Karl-Fischer titration method was applied to determine water content. The pellet-like samples were broken into pieces about $2 \mathrm{~mm}$ in length, and hydrated in wet Ar with a water partial pressure of 0.05 atm at desired temperature. Readers are referred to our previous works [39, 40] for detailed procedures.

$\mathrm{Ni}$, Cu or Zn K-edge X-ray absorption near-edge structure (XANES) measurements were performed at the SPring-8 synchrotron radiation facility (Hyogo, Japan) by using a Si(111) double-crystal monochromator at beamlines BL16B2 at $20 \mathrm{~K}$ in a vacuum and BL05XU in ambient environment with the approval of the Japan Radiation Research Institute (JASRI) (Proposal No. 2015A5330 and 2017A1797). The samples of BZY20 added nominally with $0.2 \mathrm{wt} \% \mathrm{NiO}$, $\mathrm{CuO}$ or $\mathrm{ZnO}$ were measured in fluorescence mode. Whereas data of reference samples of $\mathrm{Ni}$, $\mathrm{Cu}$ or $\mathrm{Zn}$ metal, and their binary oxides were collected in transmission mode

\subsection{Electrochemical Measurements}

Conductivity measurements of the pellet-like samples with sputtered platinum (Pt) electrodes were performed in dry or wet atmosphere of $\mathrm{H}_{2}$ or $\mathrm{O}_{2}$. The partial pressure of water vapor in the wet 
atmosphere was 0.05 atm. Pt plates wrapped with silver mesh were used as current collector. Pt wire was used to lead the current to a frequency response analyzer (Solartron SI 1260, Solartron Analytical, Farnborough, UK). The impedance spectra were collected in the frequency range from $10 \mathrm{~Hz}$ to $7 \mathrm{MHz}$ with applied voltage of $100 \mathrm{mV}$ during cooling from 700 to $100{ }^{\circ} \mathrm{C}$ at $0.2{ }^{\circ} \mathrm{Cmin}^{-1}$, and were lately analyzed using a commercial software ZView (Scribner Association Inc., NC, USA) Transport numbers of different charge carriers (protons, oxide ions, electronic holes and electrons) in humid hydrogen or oxygen atmospheres were determined by the electromotive force (EMF) method performed at 600 and $700{ }^{\circ} \mathrm{C}$ with the compensated electrode resistance. Hydrogen concentration cells, oxygen concentration cells, and water vapor concentration cells were established with the EMF values collected. The partial pressure of water vapor $\left({ }_{\mathrm{H}_{2} \mathrm{O}}\right)$ in the hydrogen and oxygen concentration cells was kept constantly as $0.0312 \mathrm{~atm}$. And $p_{\mathrm{H}_{2} \mathrm{O}}$ in the water vapor concentration cells was 0.0312 and 0.0086 atm at the two opposite electrodes. The detailed information on the EMF measurements can be found in our previous works $[8,41]$. The transport numbers evaluated in the oxygen atmosphere were compensated by taking the effect of electrode polarization into consideration [42, 43].

\section{Results}

\subsection{Composition Analysis and Microstructure Observation of As-Sintered Samples}

The actual content of $\mathrm{Ni}, \mathrm{Cu}$, and $\mathrm{Zn}$ determined by ICP-AES (at\%) was plotted against the nominal 
content of relevant binary oxide (wt\%) in Fig. 2. It should be noted that in this work, both wt\% and at $\%$ were used; wt $\%$ for the nominal content of $\mathrm{NiO}, \mathrm{CuO}$ or $\mathrm{ZnO}$, and at $\%$ for the actual value of the cations measured by ICP-AES or STEM-EDS. From Fig. 2, one can see that the actual composition is lower than the nominal value. And the loss of $\mathrm{Cu}$ and $\mathrm{Zn}$ was more serious than $\mathrm{Ni}$, possibly due to the instability of $\mathrm{ZnO}$ (decomposing to $\mathrm{Zn}(\mathrm{g})$ and $\mathrm{O}_{2}$ ) and higher vapor pressure of $\mathrm{CuO}(\mathrm{g})$ at the sintering temperature (Fig. S1). Then, the as-sintered samples of BZY20 added with 2 wt\% NiO, $\mathrm{CuO}$ or $\mathrm{ZnO}$ were picked out to check the local composition at intra-grain and grain boundary with STEM-EDS point analysis (an example is given in Fig. S2 and Table S1). Since the spot size of the electron beam of STEM-EDS is about $1 \mathrm{~nm}$, the local composition can be determined precisely. As shown in Table 2, one can see that the grain boundary area has relatively higher $\mathrm{Ni}$, Cu or Zn content than that at the intra-grain area. For example, the $\mathrm{Cu}$ content at intra-grain and grain boundary was 0.48 and 2.03 at\%, respectively. The microstructure was observed by EPMA (Fig. S3), and in agreement with the literature; that is, poor sinterability of BZY20 when heated at $1500{ }^{\circ} \mathrm{C}$ for $10 \mathrm{~h}$ can be effectively improved by adding even a small amount (0.2 wt\%) sintering additive.

\subsection{Hydration Behavior}

The proton concentration per unit cell was determined by using Karl-Fischer titration method to measure the water content in the samples which were heated in $\mathrm{Ar}-5 \% \mathrm{H}_{2} \mathrm{O}$ at desired temperature for hydration. As shown in Fig. 3, BZY20 without adding any sintering additive shows the highest 
proton concentration. With the increasing temperature and concentration of $\mathrm{Ni}$, $\mathrm{Cu}$ or $\mathrm{Zn}$, the proton concentration decreases. The results indicate clearly a negative effect on incorporation of protons into BZY20 by adding $\mathrm{NiO}, \mathrm{CuO}$ or $\mathrm{ZnO}$.

Then, the HT-XRD measurements were performed in dry oxygen and humid oxygen $\left(p_{\mathrm{H}_{2} \mathrm{O}}=0.031\right.$ atm) to collect the information on change of lattice constants with the humidity and amount of sintering additive. The lattice constants were determined by Rietveld refinement using a cubic perovskite model $(\operatorname{Pm} \overline{3} m)[44,45]$, and tend to decrease with the increasing amount of $\mathrm{NiO}, \mathrm{CuO}$ or $\mathrm{ZnO}$, as shown in Fig. 4. Furthermore, the lattice constants obtained in the wet oxygen atmosphere are larger than those in the dry atmosphere, indicating a clear chemical expansion effect induced by hydration. Then, following the approach reported in our previous works [3, 45, 46], a quantitative evaluation on the effect of chemical expansion was conducted by using Eq. (1), in which $a_{\mathrm{dry} \mathrm{O}_{2}}$ and $a_{\mathrm{wet} \mathrm{O}_{2}}$ are the lattice constants in dry and wet oxygen atmosphere, respectively. As shown in Fig. 5, the change ratio of lattice constant increases with the increasing proton concentration, and decreases with the increasing content of $\mathrm{Ni}, \mathrm{Cu}$ and $\mathrm{Zn}$. It is quite reasonable, since the chemical expansion is induced by hydration which incorporates protons, whereas increasing the amount of $\mathrm{NiO}, \mathrm{CuO}$ or $\mathrm{ZnO}$ results in a reduction in the capability for proton incorporation.

$$
\text { change ratio of lattice constant }=\frac{a_{\text {wet } \mathrm{O}_{2}}-a_{\mathrm{dry}}}{a_{\mathrm{dry}}} \times 100 \%
$$




\subsection{Electrical Conductivity}

The electrical conductivity was determined by analysing the impedance spectra, which were collected through three continuous cycles in different atmosphere. Since the samples were sintered in the oxygen atmosphere, the first cycle was performed in wet $\mathrm{O}_{2}$ during cooling from $700{ }^{\circ} \mathrm{C}$ to $100{ }^{\circ} \mathrm{C}$ after the conductivity was stabilized at $700{ }^{\circ} \mathrm{C}$. Then, the samples were annealed at $700{ }^{\circ} \mathrm{C}$ in wet $\mathrm{H}_{2}$ for $10 \mathrm{~h}$, followed by a subsequent running of the second cycle. Finally, the atmosphere was altered to wet $\mathrm{O}_{2}$ again for the third cycle. Through such designed sequence, not only the dependence of the conductivity on the amount of sintering additives, but also the redox properties of the samples can be revealed.

The impedance spectra of the samples added nominally with $0.5 \mathrm{wt} \% \mathrm{NiO}, \mathrm{CuO}$ or $\mathrm{ZnO}$ are given in Fig. 6 for example. The semi-circles appear at the high and middle frequency ranges are attributed to the resistance from bulk (intra-grain) and grain boundary, respectively, judged from their specific capacitance around $10^{-11}$ and $10^{-9} \mathrm{~F}$, respectively [3, 47]. By taking the geometric factors (thickness and area) into consideration, the bulk, grain boundary, and total conductivities were determined (see Electronic Supplementary Information for Arrhenius plots). Since in most cases, the semicircles belonging to the bulk and grain boundary resistances are only distinguishable up to around $300{ }^{\circ} \mathrm{C}$ (an example of BZY20 - 0.5 wt\% NiO is given in Fig. S4), for the sake of comparison, the bulk and grain boundary conductivities at $300{ }^{\circ} \mathrm{C}$ are picked out and plotted in Figs. $\mathbf{7}$ and $\mathbf{8}$, respectively. The temperature of $300{ }^{\circ} \mathrm{C}$ is selected because transport number of proton at such low temperature is close 
to unity according to the EMF measurement in the later section.

As shown in Fig. 7, the bulk conductivity measured at $300{ }^{\circ} \mathrm{C}$ in the first cycle in wet $\mathrm{O}_{2}$, in general, decreased with the increasing cation ratio of $\mathrm{Ni}, \mathrm{Cu}$ or $\mathrm{Zn}$, which indicates clearly a negative effect on the bulk conductivity by adding $\mathrm{NiO}, \mathrm{CuO}$ or $\mathrm{ZnO}$. When the atmosphere was altered to wet $\mathrm{H}_{2}$ (the second cycle), reduction in bulk resistance (Fig. 7), and correspondingly, enhancement in bulk conductivity were observed. Especially, in the case of adding $\mathrm{CuO}$ (Fig. 7(b)), the bulk conductivity in wet $\mathrm{H}_{2}$ is even higher than that of the pure BZY20. After the atmosphere was returned to wet $\mathrm{O}_{2}$ again (the third cycle), the conductivity decreased, but are still obviously higher than that measured in the first cycle in wet $\mathrm{O}_{2}$.

The behaviour of grain boundary conductivity at $300{ }^{\circ} \mathrm{C}$ (Fig. 8) is relatively complicated, since there is no clear relationship in the magnitude among different cycles. For example, for the samples added with $\mathrm{NiO}$, the grain boundary conductivity measured in the first cycle in wet $\mathrm{O}_{2}$ is the highest, but for the $\mathrm{CuO}$ or $\mathrm{ZnO}$-added samples, the highest grain boundary conductivity was obtained in the second cycle in wet $\mathrm{H}_{2}$. However, qualitatively, the grain boundary conductivity also tends to decrease with the increasing cation ration of $\mathrm{Ni}, \mathrm{Cu}$ or $\mathrm{Zn}$, and is apparently smaller than the bulk conductivity. The total conductivity at $600{ }^{\circ} \mathrm{C}$, which is typical temperature for fuel cell operation, is shown in Fig. 9. The total conductivity also shows the tendency to decrease with the increasing amount of NiO, $\mathrm{CuO}$ or $\mathrm{ZnO}$ additives. At $600{ }^{\circ} \mathrm{C}$, the contribution of hole conduction is enhanced $[8,48]$, and the conductivities in wet $\mathrm{O}_{2}$ in some samples are relatively higher than that measured in wet $\mathrm{H}_{2}$. 


\subsection{Transport Numbers}

The EMF method was applied to determine the transport numbers of various charge carriers, including protons, oxide ions, and electronic holes in the samples added with $2 \mathrm{wt} \% \mathrm{NiO}, \mathrm{CuO}$ or $\mathrm{ZnO}$. The voltage measured in the hydrogen concentration cells are very close to the Nernst voltage, indicating that regardless of $\mathrm{NiO}, \mathrm{CuO}$ or $\mathrm{ZnO}$ additive, almost pure ionic conduction (protons and oxide ions) occurred (Fig. S16). However, in the mode of oxygen concentration cells, the measured voltage is obviously lower than the Nernst voltage (Fig. S17), implying generation of significant contribution of hole conduction. Here, compensation was performed in wet oxidizing atmosphere by taking the electrode polarization effect into consideration [8, 42].

As shown in Fig. 10, regardless of whether $\mathrm{NiO}, \mathrm{CuO}$ or $\mathrm{ZnO}$ was added into BZY20, almost pure ionic conduction, mainly proton conduction, occurred in hydrogen atmosphere. However, when exposing to the oxygen atmosphere, even in the case of pure BZY20, the transport number of ionic conduction deviates obviously from unity. And further reduction in the contribution of the ionic conduction was confirmed by adding the sintering additives. For example, the transport number of ionic conduction at $600{ }^{\circ} \mathrm{C}$ in the pure BZY20 sample is about 0.69 , but decreased greatly to $0.34,0.39$ and 0.43 , when $2 \mathrm{wt} \% \mathrm{NiO}, \mathrm{CuO}$ and $\mathrm{ZnO}$ was added, respectively. These results definitely show negative impact on the ionic conduction in BZY20 when $\mathrm{NiO}$, $\mathrm{CuO}$ or $\mathrm{ZnO}$ was added.

Such enhancement in the contribution of hole conduction might correlate with the decreased capability for proton introduction. The protons are incorporated into barium zirconate through hydration 
reaction given in Equation (2). However, as shown in Figure 3, the proton concentration decreased with the increasing $\mathrm{Ni}$ concentration, indicating that less oxide ion vacancies $\left(\mathrm{V}_{\circ}^{*}\right)$ participate in the hydration reaction and are available for the reaction given in Equation (3) to form electronic holes $\left(\mathrm{h}^{\bullet}\right)$. However, the hole conduction was influenced not only by the concentration, but also the mobility of the holes, which might also change when these sintering additives were added.

$$
\begin{gathered}
\mathrm{H}_{2} \mathrm{O}+\mathrm{V}_{\mathrm{O}}^{\bullet \bullet}+\mathrm{O}_{\mathrm{O}}^{\times}=2 \mathrm{OH}_{\mathrm{O}}^{\bullet} \\
\mathrm{O}_{2}+2 \mathrm{~V}_{\mathrm{O}}^{\bullet \bullet}=2 \mathrm{O}_{\mathrm{O}}^{\times}+4 \mathrm{~h}^{\bullet}
\end{gathered}
$$

\subsection{Post-Annealing in Hydrogen}

Since $\mathrm{NiO}, \mathrm{CuO}$ and $\mathrm{ZnO}$ influence negatively the capability of proton incorporation and electrical properties of BZY20, whether they can be excluded, for example, by post-annealing in reducing atmosphere, appears to be an interesting and meaningful topic. Our previous work on the BZY20$\mathrm{NiO}$ system shows that $\mathrm{Ni}$ cations, possibly taking trivalent state, incorporate into the cubic perovskite crystal structure of BZY20, and mainly occupy an interstitial position between two adjacent Ba cations, resulting in formation of Ba vacancies due to the electrostatic repulsion [33]. These Ni cations can be entirely excluded to the grain boundary of BZY20 in the form of Ni metal particles by annealing at $1400{ }^{\circ} \mathrm{C}$ in Ti-deoxidized Ar atmosphere, but can hardly be excluded at $600{ }^{\circ} \mathrm{C}$ in pure hydrogen [34]. Meanwhile, Nasani, et al. [49] and Polfus et al. [50] found that the exclusion of nickel can be partially realized in hydrogen at relatively higher temperature, such as 750 and $800{ }^{\circ} \mathrm{C}$. Here, at the annealing 
temperature of $700{ }^{\circ} \mathrm{C}$ in this work, we want to see whether the same exclusion phenomenon can occur, especially in the system added with $\mathrm{CuO}$ or $\mathrm{ZnO}$, which was not reported.

Firstly, the samples of BZY20 added with $2 \mathrm{wt} \% \mathrm{NiO}, \mathrm{CuO}$ or $\mathrm{ZnO}$ were annealed in dry $\mathrm{H}_{2}$ at 700 ${ }^{\circ} \mathrm{C}$ for $48 \mathrm{~h}$, then subjected to STEM-EDS point analysis to determine the local composition in intragrain and grain boundary area with the results summarized in Table 2. For the BZY20 - 2 wt\% NiO sample, the Ni cation ratio in the intra-grain and grain boundary area is 1.92 and 2.34 at\%, respectively, close to the values of 1.93 and 2.50 at $\%$ for the as-sintered sample $\left(1500{ }^{\circ} \mathrm{C}, \mathrm{O}_{2}, 10 \mathrm{~h}\right)$. The case of the BZY20 - 2 wt\% ZnO sample is similar. However, the sample added with $2 \mathrm{wt} \% \mathrm{CuO}$ behaves differently; that is, the $\mathrm{Cu}$ cation ratio in the intra-grain and grain boundary area of the as-sintered sample is about 0.48 and 2.03 at\%, and decreases greatly to 0.24 and 0.38 at\%, respectively, after annealing in $\mathrm{H}_{2}$ at $700{ }^{\circ} \mathrm{C}$. We suppose that $\mathrm{Cu}$ metal particles might segregate at the grain boundary of BZY20 as a consequence. However, possibly due to the very small area available for TEM observation, we were unable to confirm the segregation of any Cu metal particle.

The analysis on the $2 \mathrm{wt} \% \mathrm{NiO}, \mathrm{CuO}$ or $\mathrm{ZnO}$-contained samples only indicates that copper can be effectively excluded from BZY20. Then we carried out XANES measurement to confirm existence of metal copper. XANES measurements on the samples containing reduced amount, i.e. $0.2 \mathrm{wt} \%$, of $\mathrm{NiO}, \mathrm{CuO}$ or ZnO, provided additional interesting information. As shown in Fig. 11, the XANES spectra of all the as-sintered samples are obviously different from those of the corresponding reference samples, implying that most of $\mathrm{NiO}, \mathrm{CuO}$ or $\mathrm{ZnO}$ incorporated successfully into the crystal structure 
of BZY20, rather than remained as their binary oxides. But, after annealing in hydrogen at $700{ }^{\circ} \mathrm{C}$ for $48 \mathrm{~h}$, the spectrum of BZY20 - $0.2 \mathrm{wt} \% \mathrm{NiO}$ turns to be close to that of Ni metal. The spectrum of BZY20 - $0.2 \mathrm{wt} \% \mathrm{CuO}$ also changed, and is obviously different from that of $\mathrm{CuO}$. It is difficult to determine whether the spectrum is close to $\mathrm{Cu}$ or $\mathrm{Cu}_{2} \mathrm{O}$. But, since the spectrum shifted towards the low energy side, it is definite that the oxidation state of $\mathrm{Cu}$ cations is reduced. However, the spectrum of BZY20 - $0.2 \mathrm{wt} \% \mathrm{ZnO}$ does not change much from that of the as-sintered one.

\section{Discussion}

\subsection{Exclusion of nickel and copper from intra-grain of BZY20 and correlation with conductivity}

Evidently, it can be concluded that copper and nickel are available to be excluded from BZY20 after post-annealing at $700{ }^{\circ} \mathrm{C}$ in hydrogen. And the exclusion of copper seems to be much more kinetically favourable, since clear decrease of the $\mathrm{Cu}$ concentration at both the intra-grain and grain boundary area was confirmed in the post-annealed BZY20 - $2 \mathrm{wt} \%$ CuO sample. Comparably, exclusion of nickel appears to be more difficult. In our previous work [33], post-annealing the BZY20 sample containing about 0.40 at $\% \mathrm{Ni}$ at $600{ }^{\circ} \mathrm{C}$ in hydrogen for $24 \mathrm{~h}$ only results in a slight shift in the Ni K-edge XANES spectra without obvious change in the shape of the spectra (also plotted in Fig. 11(a) for comparison). But in this work, annealing the BZY20 - $0.2 \mathrm{wt} \% \mathrm{NiO}(0.39 \mathrm{at} \% \mathrm{Ni}$ by ICP-AES) sample at higher temperature of $700{ }^{\circ} \mathrm{C}$ for longer time of $48 \mathrm{~h}$ leads to the XANES spectrum approaching to the metal Ni reference, but notably, not entirely the same as the Ni reference, 
indicating that a part of nickel incorporated into BZY20 remained in the oxide structure. However, we did not observe clear change in intra-grain Ni concentration in the BZY20 - 2 wt\% NiO sample before and after the post-annealing in hydrogen. One possible reason might be attributed to the different grain size of BZY20 achieved by adding different amount of NiO; about $1 \mu \mathrm{m}$ for BZY20 $0.2 \mathrm{wt} \% \mathrm{NiO}$, whereas larger than $5 \mu \mathrm{m}$ for $\mathrm{BZY} 20-2 \mathrm{wt} \% \mathrm{NiO}$. The larger grain size needs longer time for nickel to be obviously excluded from the intra-grain, which is actually a diffusion process. Furthermore, partial exclusion of nickel was reported by annealing $\mathrm{NiO}$-added $\mathrm{BaZr}_{0.85} \mathrm{Y}_{0.15} \mathrm{O}_{3-\delta}$ (grain size around $3 \mu \mathrm{m}$ ) at higher temperature of 750 [49] and $800{ }^{\circ} \mathrm{C}$ [50] for 15 and $24 \mathrm{~h}$, respectively. So, it can be concluded that nickel can be excluded from barium zirconate at such mild temperature, but the process is kinetically slow. Entire exclusion of nickel might require quite high temperature or long time, for example, $1400{ }^{\circ} \mathrm{C}$ for $100 \mathrm{~h}$ in the Ti-deoxidized Ar atmosphere as reported in our previous work [34].

The electrical conductivity no doubt will be influenced by the annealing in hydrogen with consequent exclusion of nickel and copper. One can see that after annealing the samples added with $\mathrm{NiO}$ or $\mathrm{CuO}$ at $700{ }^{\circ} \mathrm{C}$ in wet hydrogen for $10 \mathrm{~h}$ during the second cycle for conductivity measurement, the bulk conductivity increased over that of the first cycle in wet oxygen. But, exclusion of nickel or copper is not the only reason for the recovery of bulk conductivity. Since nickel incorporated into the crystal structure of barium zirconate takes the form of trivalent nickel cations [33], exposure to hydrogen will thereby reduce a part of these trivalent nickel cations $\left(\mathrm{Ni}_{\mathrm{i}}^{\cdots}{ }^{\cdots}\right)$ to lower valence state, such as divalent 
$\left(\mathrm{Ni}_{\mathrm{i}}\right)$, or perhaps to metallic state with incorporating proton into bulk and changing the activation energy to favour the migration of protons. Further exposure to the oxygen atmosphere (the third cycle) causes the nickel cations return to the trivalent state. The conductivity decrease in consequence, but will not completely return to the value collected at the first cycle in oxygen, because a part of nickel has already been excluded from barium zirconate. Of course, the extent of returning of the conductivity is different with the grain size. Such behaviour of conductivity obtained among different cycles is quite clear in the sample with high amount of $\mathrm{NiO}$ additive, e.g., $2 \mathrm{wt} \%$ (Fig. S5(d)). The conductivity behaviour of the samples added with $\mathrm{CuO}$ appears to be similar, however, the bulk conductivity measured in the wet hydrogen atmosphere increased surprisingly, even higher than that of the pure BZY20. The reason is not clear, but one hypothesis is that in the reducing atmosphere, in addition to be excluded as copper metal, a part of the copper cations might be reduced to lower valences state, such as from $\mathrm{Cu}(\mathrm{II})$ to $\mathrm{Cu}(\mathrm{I})$, resulting in a local lattice expansion surrounding these copper cations because generally, tensional stress on barium zirconate benefits the proton conduction [51]. However, such hypothesis needs further investigation in future.

In the case of the samples added with $\mathrm{ZnO}$, we also observed a clear enhancement in the bulk conductivity when the atmosphere was altered from wet oxygen (the first cycle) to wet hydrogen (the second cycle). But the composition changes in the BZY20 - 2 wt $\%$ ZnO sample is little and the spectrum of BZY20 - 0.2 wt $\% \mathrm{ZnO}$ does not change so much in hydrogen. At present, we do not have any hypothesis to explain these behaviours clearly. 


\subsection{Current Fabrication Method of Anode-Supported Cells and Perspective}

Currently, the most common structure for BZY20 electrolyte-based cells is the anode-supported one coupled with the co-sintering process with the sintering additive optionally added, which allows the implementation of the electrolyte layers thinned to be tens of micrometers with minimized loss in ohmic resistance. In fact, not only fuel cells, but also some other electrochemical devices, including cells of electrolyzer [52, 53], hydrogen separation [54, 55] and methane reforming [56, 57], were fabricated with such method. However, as clarified in our preliminary experiment (Fig. 1), regardless of whether sintering additives were added on purpose or not, $\mathrm{NiO}$ in the anode diffuses into the electrolyte layer and plays the role of the sintering additive. Reviewing the literature reveals that the co-sintered cells have the conductivity around 0.001 to $0.003 \mathrm{Scm}^{-1}$ (Table 1), in accordance with the results in this work; that is, the BZY20 sample added with 1 or 2 wt\% NiO shows the conductivity (mainly proton conduction) lower than $0.004 \mathrm{Scm}^{-1}$ in wet hydrogen (Fig. 9). Furthermore, the open circuit voltage values are all not higher than $1.01 \mathrm{~V}$, obviously lower than the Nernst voltage around $1.14 \mathrm{~V}$, which is a direct result from the enhanced hole conduction in BZY20 affected by adding NiO, $\mathrm{CuO}$ or $\mathrm{ZnO}$. It is worth to note that people may mistakenly expect that the hole conduction in BZY20 electrolyte generated at the cathode side can be blocked by the anode side. But actually, chemical potential of oxygen does not linearly distribute across the electrolyte. It keeps high to the vicinity of the anode side, and drops dramatically [36]. So, even BZY20 shows pure ionic conduction in hydrogen, the leakage current generated due to the hole conduction can not be ignored. 
Considering the case of a co-sintered fuel cell, which has an electrolyte layer with the thickness and conductivity typically of $25 \mu \mathrm{m}$ and $0.002 \mathrm{Scm}^{-1}$, respectively, the pure BZY20 electrolyte (proton conductivity around $0.01 \mathrm{Scm}^{-1}$ ) showing comparable performance will be allowed to be thicker for 5 times (namely, $125 \mu \mathrm{m}$ ) but even with less hole conduction. So, strategy of adding these sintering additives, or co-sintering a $\mathrm{NiO}$ anode stood cell faces quite severe challenge to improve the cell performance, and it appears to be meaningless if one still uses the co-sintering method to develop the NiO anode-supported fuel cells with the BZY electrolyte.

Reports on using pulsed laser deposition (PLD) method to prepare the BZY electrolyte provide a clear and attractive image on how well the fuel cells should perform with a pure BZY electrolyte, since the PLD method is able to directly deposit dense BZY electrolyte layer with good crystallinity. Pergolesi, et al. [21] reported a fuel cell with $4 \mu \mathrm{m}$ thick BZY20 electrolyte, showing the peak power density of $110 \mathrm{mWcm}^{-2}$ at $600{ }^{\circ} \mathrm{C}$. Recently, Bae, et al. [30] demonstrated a high performance fuel cell with a PLD-prepared thin $\mathrm{BaZr}_{0.85} \mathrm{Y}_{0.15} \mathrm{O}_{3-\delta}(\mathrm{BZY} 15)$ electrolyte deposited on a BZY15 - 56 wt\% NiO anode. The peak power density achieved remarkably $740 \mathrm{mWcm}^{-2}$ at $600{ }^{\circ} \mathrm{C}$, and they attributed such great improvement only to successfully thinning the electrolyte to $2.5 \mu \mathrm{m}$. But another important reason should be the success in preparing the thin electrolyte layer without NiO. According to this study, eliminating $\mathrm{NiO}$ from the electrolyte leads high OCV and high proton conductivity. In fact, relatively high OCV were reported. However, we need discussion about the conductivity. Using the ohmic resistance and thickness of the electrolyte layer, the conductivity of the BZY20 and BZY15 electrolyte 
layers in the works of Pergolesi, et al. [21] and Bae, et al. [30] is estimated to be 0.00021 and 0.00278 $\mathrm{Scm}^{-1}$, respectively. But these values are about one tenth small in comparison with the conductivity of the pellet sample. One of reason might be off stoichiometry and another reason is ohmic resistance in electrode layers. The anode substrate in the work of Pergolesi, et al. [21] contains only 26 wt\% $\mathrm{NiO}$, far from the appropriate $\mathrm{NiO}$ content about 40 - $70 \mathrm{wt} \%[58,59]$. And Bae, et al. [30] inserted a functional layer composed of nano-sized BZY15 and NiO particles between the electrolyte and anode layers. Therefore, the measured ohmic resistance may not reflect solely the contribution from the electrolyte layer. At present, the PLD method is still high cost, and not available to deposit thin films with large scale. [60] In addition to such problems, the process to apply PLD on depositing BZY also needs to be optimized for fuel cell application.

In our opinion, to further develop the anode-supported fuel cells with the BZY electrolyte, some new discovery and technology for processing is essential. For example, finding a new sintering additive which is not detrimental to the electroconductive properties of BZY, developing an alternative anode material which does not react with BZY during the co-sintering, or designing a cost-effective new process which does not need the co-sintering step, or does not induce the reaction between BZY and $\mathrm{NiO}$. At least, the negative effect on adding the sintering additives of $\mathrm{NiO}, \mathrm{CuO}$ and $\mathrm{ZnO}$, and also the problem on diffusion of $\mathrm{NiO}$ into the electrolyte during the co-sintering, should be sufficiently recognized. 


\section{Conclusions}

In this work, a systematic investigation was performed to study the effect of $\mathrm{NiO}, \mathrm{CuO}$ and $\mathrm{ZnO}$ on the electroconductive properties of $\mathrm{BaZr}_{0.8} \mathrm{Y}_{0.2} \mathrm{O}_{3-\delta}$ (BZY20). The results revealed that although adding these oxides improved the sinterability of BZY20, significant reduction in capability of proton incorporation and proton conductivity occurred, together with enhancement in hole conduction. The added $\mathrm{NiO}$, $\mathrm{CuO}$ or $\mathrm{ZnO}$ sintering additive can be, in some cases, lately excluded out of BZY20 by post-annealing in the hydrogen atmosphere at mild temperature, such as $700{ }^{\circ} \mathrm{C}$, but such process is kinetically slow. Therefore, in conclusion, adding $\mathrm{NiO}, \mathrm{CuO}$ and $\mathrm{ZnO}$ imposes detrimental impact on the electroconductive properties of BZY20, thereby restricts its application as sintering additives. It is worth to note that, even without deliberately adding these sintering additives, $\mathrm{NiO}$ in the anode also diffuses into the BZY20 electrolyte layer, and plays the same role as the sintering additive. So, developing new sintering additives, new anode catalysts or new processing for preparing the BZY electrolyte-based cells is an urgent task.

\section{Acknowledgements}

This work was partially supported by the New Energy and Industrial Technology Development Organization (NEDO) in Japan (Project code P14004). The authors want to thank Mr. Kenji Kazumi for STEM observation. 


\section{References}

[1] B.C.H. Steele, A. Heinzel, Nature 2001, 414, 345 - 352.

[2] A. Dubois, S. Ricote, R.J. Braun, J. Power Sources 2017, 369, 65 - 77.

[3] D. Han, K. Shinoda, S. Sato, M. Majima, T. Uda, J. Mater. Chem. A 2015, 3, 1243 - 1250.

[4] D. Han, N. Hatada, T. Uda, J. Am. Ceram. Soc. 2016, 99, 3745 - 3753.

[5] E. Gilardi, E. Fabbri, L. Bi, J.L.M. Rupp, T. Lippert, D. Pergolesi, E. Traversa, J. Phys. Chem. C, 2017, 121, 9739 - 9747.

[6] D. Pergolesi, E. Fabbri, A. D’Epifanio, E.D. Bartolomeo, A. Tebano, S. Sanna, S. Licoccia, G. Balestrino, E. Traversa, Nat. Mater. 2010, 9, 846 - 852.

[7] Y. Yamazaki, R. Hernandez-Sanchez, S.M. Haile, Chem. Mater. 2009, 21, 2755 - 2762.

[8] D. Han, Y. Noda, T. Onishi, N. Hatada, M. Majima, T. Uda, Int. J. Hydrogen Energy 2016, 41, 14897 - 14908.

[9] K. Kato, D. Han, T. Uda, J. Am. Ceram. Soc. 2018, doi: 10.1111/jace.15946.

[10] K. Katahira, Y. Kohchi, T. Shimura, H. Iwahara, Solid State Ionics 2000, 138, 91 - 98.

[11] Y. Guo, Y. Lin, H. Shi, R. Ran, Z. Shao, Chin, J. Catal. 2009, 30, 479 - 481.

[12] P. Babilo, S.M. Haile, J. Am. Ceram. Soc. 2005, 88, 2362 - 2368.

[13] J. Tong, D. Clark, M. Hoban, R. O’Hayre, Solid State Ionics 2010, 181, 496 - 503.

[14] J. Tong, D. Clark, L. Bernau, M. Sanders, R. O’Hayre, J. Mater. Chem. 2010, 20, 6333 - 6341.

[15] S. Nikodemski, J. Tong, R. O’Hayre, Solid State Ionics 2013, 253, 201 - 210. 
[16] K. Park, Y. Seo, K.B. Kim, S. Song, B. Park, J. Park, J. Alloy. Compd. 2015, 639, 435 - 444.

[17] S. Tao, J.T.S. Irvine, Adv. Mater. 2006, 18, 1581 - 1584.

[18] S. Tao, J.T.S. Irvine, J. Solid State Chem. 2007, 180, 3493 - 3503.

[19] J.T.S. Irvine, A. Kruth, C.D. Savaniu, S. Tao, Steam Electrolysis, US Pat., 7906006B2, 2011(filing date Mar.24, 2005).

[20] C. Duan, J. Tong, M. Shang, S. Nikodemski, M. Sanders, S. Ricote, A. Almansoori, R. O’Hayre, Science 2015, 349, 1321 - 1326.

[21] C. Duan, R.J. Kee, H. Zhu, C. Karakaya, Y. Chen, S. Ricote, A. Jarry, E.J. Crumlin, D. Hook, R. Braun, N.P. Sullivan, R. O’Hayre, Nature 2018, 557, 217-222.

[22] W. Sun, L. Yan, Z. Shi, Z. Zhu, W. Liu, J. Power Sources 2010, 195, 4727 - 4730.

[23] D. Pergolesi, E. Fabbri, E. Traversa, Electrochem. Commun. 2010, 12, 977 - 980.

[24] E. Fabbri, L. Bi, H. Tanaka, D. Pergolesi, E. Traversa, Adv. Func. Mater. 2011, 21, 158 - 166.

[25] L. Bi, E. Fabbri, Z. Sun, E. Traversa, Energy Environ. Sci. 2011, 4, 1352 - 1357.

[26] Z. Sun, E. Fabbri, L. Bi, E. Traversa, J. Am. Ceram. Soc. 2012, 95, 627 - 635.

[27] J. Xiao, W. Sun, Z. Zhu, Z. Tao, W. Liu, Mater. Lett. 2012, 73, 198 - 201.

[28] I. Luisetto, S. Licoccia, A. D’Epifanio, A. Sanson, E. Mercadelli, E.D. Bartolomeo, J. Power Sources 2012, 220, 280 - 285.

[29] Y. Liu, Y. Guo, R. Ran, Z. Shao, J. Membr. Sci. 2012, 415 - 416, 391 - 398.

[30] W. Sun, Z. Shi, M. Liu, L. Bi, W. Liu, Adv. Func. Mater. 2014, 24, 5695 - 5702. 
[31] S.P. Shafi, L. Bi, S. Boulfrad, E. Traversa, J. Electrochem Soc. 2015, 162, F1498 - F1503.

[32] K. Bae, D.Y. Jang, H.J. Choi, D. Kim, J. Hong, B. Kim, J. Lee, J. Son, J.H. Shim, Nat. Commun. 2017, 14553.

[33] L. Bi, E.H. Da’as, S.P. Shafi, Electrochem. Commun. 2017, 80, 20 - 23.

[34] H. Dai, Ceram. Int. 2017, 43, 7362 - 7365.

[35] D. Han, K. Shinoda, S. Tsukimoto, H. Takeuchi, C. Hiraiwa, M. Majima, T. Uda, J. Mater. Chem. A 2014, 2, 12552 - 12560.

[36] D. Han, J. Iihara, S. Uemura, K. Kazumi, C. Hiraiwa, M. Majima, T. Uda, J. Mater. Chem. A. 2016, 4, 10601 - 10608.

[37] N. Nasani, D. Pukazhselvan, A.V. Kovalevsky, A.L. Shaula, D.P. Fagg, J. Power Sources 2017, 339, 93 - 102.

[38] T. Nakamura, S. Mizunuma, K. Yamauchi, K. Mikami, T. Kuroha, K. Amezawa, 18th International Conference on Solid State Protonic Conductors, Oslo, Norway, 2016.

[39] C. Hiraiwa, D. Han, A. Kuramitsu, A. Kuwabara, H. Takeuchi, M. Majima, T. Uda, J. Am. Ceram. Soc. 2013, 96, 879 - 884.

[40] D. Han, M. Majima, T. Uda, J. Solid State Chem. 2013, 205, 122 - 128.

[41] D. Han, Y. Okumura, Y. Nose, T. Uda, Solid State Ionics 2010, 181, 1601 - 1606.

[42] D. Han, Y. Nose, K. Shinoda, T. Uda, Solid State Ionics 2012, 213, 2 - 7.

[43] K. Shitara, T. Moriasa, A. Sumitani, A. Seko, H. Hayashi, Y. Koyama, R. Huang, D. Han, H. 
Moriwake, I. Tanaka, Chem. Mater., 2017, 29, 3763.

[44] M. Liu, H. Hu, J. Electrochem. Soc. 1996, 143, L109 - L112.

[45] V.V. Kharton, F.M.B. Marques, Solid State Ionics 2001, 140, 381 - 394.

[46] D. Han, K. Kishida, K. Shinoda, H. Inui, T. Uda, J. Mater. Chem. A 2013, 1, 3027 - 3033.

[47] D. Han, K. Shinoda, T. Uda, J. Am. Ceram. Soc. 2014, 97, 643 - 650.

[48] D. Han, K. Kato, T. Uda, Chem. Comm. 2017, 53, 12684 - 12687.

[49] S.M. Haile, D.L. West, J. Campbell, J. Mater. Res. 1998, 13, 1576 - 1595.

[50] K. Nomura, H. Kageyama, Solid State Ionics 2007, 178, 661 - 665.

[51] J.M. Polfus, M. Fontaine, A. Thøgersen, M. Riktor, T. Norby, R. Bredesen, J. Mater. Chem. A 2016, 4, $8105-8112$.

[52] A. Fluri, A. Marcolongo, V. Roddatis, A. Wokaun, D. Pergolesi, N. Marzari, T. Lippert, Adv. Sci. 2017, 1700467.

[53] L. Bi, S.P. Shafi, E. Traversa, J. Mater. Chem. A 2015, 3, 5815 - 5819.

[54] L. Lei, Z. Tao, X. Wang, J.P. Lemmon, F. Chen, J. Mater. Chem. A 2017, 5, 22945 - 22951.

[55] S. Fang, S. Wang, K.S. Brinkman, F. Chen, J. Mater. Chem. A 2014, 2, 5825 - 5833.

[56] S. Fang, S. Wang, K.S. Brinkman, Q. Su, H. Wang, F. Chen, J. Power Sources 2015, 278, 614 622.

[57] S.H. Morejudo, R. Zanón, S. Escolástico, I. Yuste-Tirados, M. Malerød-Fjeld, P.K. Vestre, W.G. Coors, A. Martínez, T. Norby, J.M. Serra, C. Kjølseth, Science, 2016, 353, 563 - 566. 
[58] H. Malerød-Fjeld, D. Clark, I. Yuste-Tirados, R. Zanón, D. Catalán-Martinez, D. Beeaff, S.H. Morejudo, P.K. Vestre, T. Norby, R. Haugsrud, R.; J.M. Serra, C. Kjølseth, Nat. Energy 2017, 2, $923-931$.

[59] L. Bi, E. Fabbri, Z. Sun, E. Traversa, J. Electrochem. Soc. 2011, 158, B797 - B803.

[60] T. Onishi, D. Han, Y. Noda, N. Hatada, M. Majima, T. Uda, Solid State Ionics 2018, 317, 127 135.

[61] E. Stefan, M. Stange, C. Denonville, Y. Larring, N. Hildenbrand, T. Norby, R. Hausgrud, J. Mater.

Sci. 2017, 52, 6486 - 6497. 
(a) Optical images

as-prepared / before co-sintering

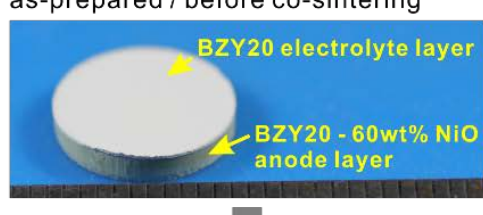

After co-sintering $\left(1500{ }^{\circ} \mathrm{C}, \mathrm{O}_{2}, 10 \mathrm{~h}\right)$

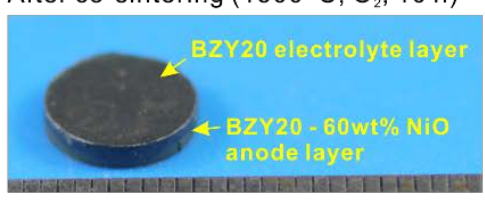

(b) EPMA-BSE image of cross-section area

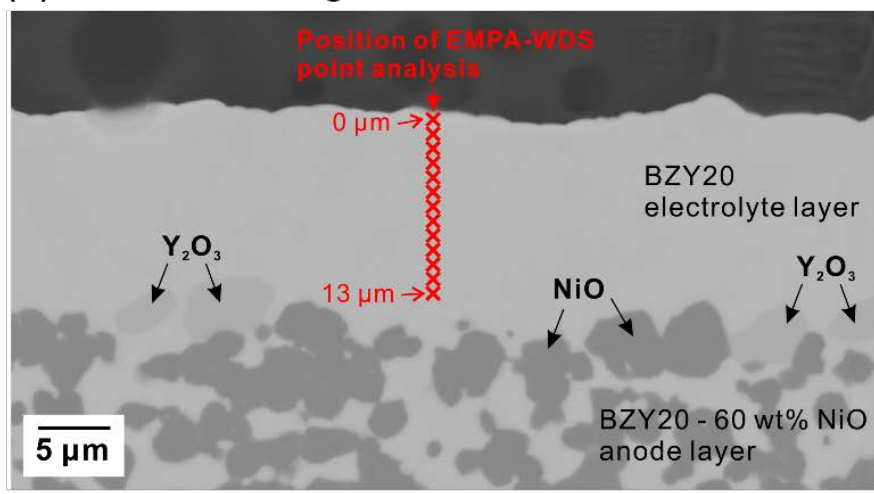

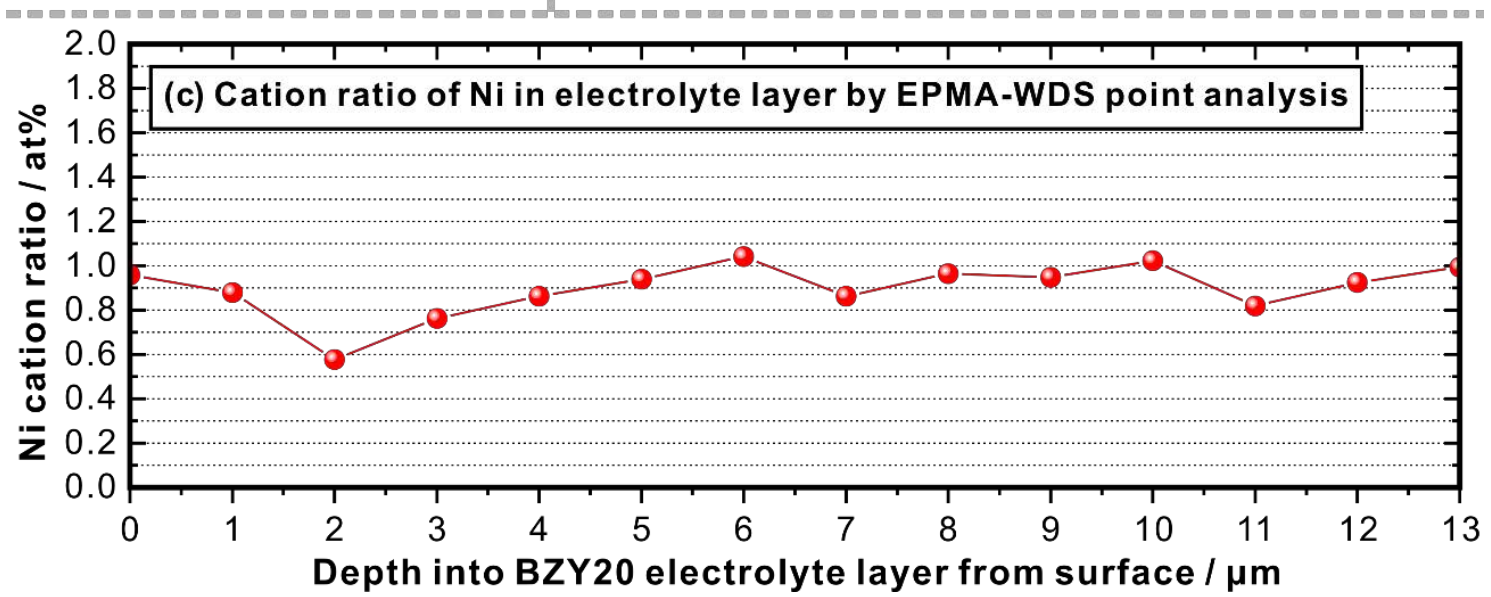

Fig. 1 Preliminary examination on a half cell composed of a BZY20 - 60 wt\% NiO anode layer and a spin-coated BZY20 electrolyte layer. (a) Optical images showing the electrolyte layer turned to be black color after co-sintering at $1500{ }^{\circ} \mathrm{C}$ in oxygen atmosphere for $10 \mathrm{~h}$. (b) An EPMA back scattering electron (EPMA-BSE) image of the cross-section area (polished by JEOL IB-19510CP Cross Section Polisher). (c) Cation ratio of Ni in the electrolyte layer by performing EPMA-WDS point analysis on the position marked with cross symbols in (b). 


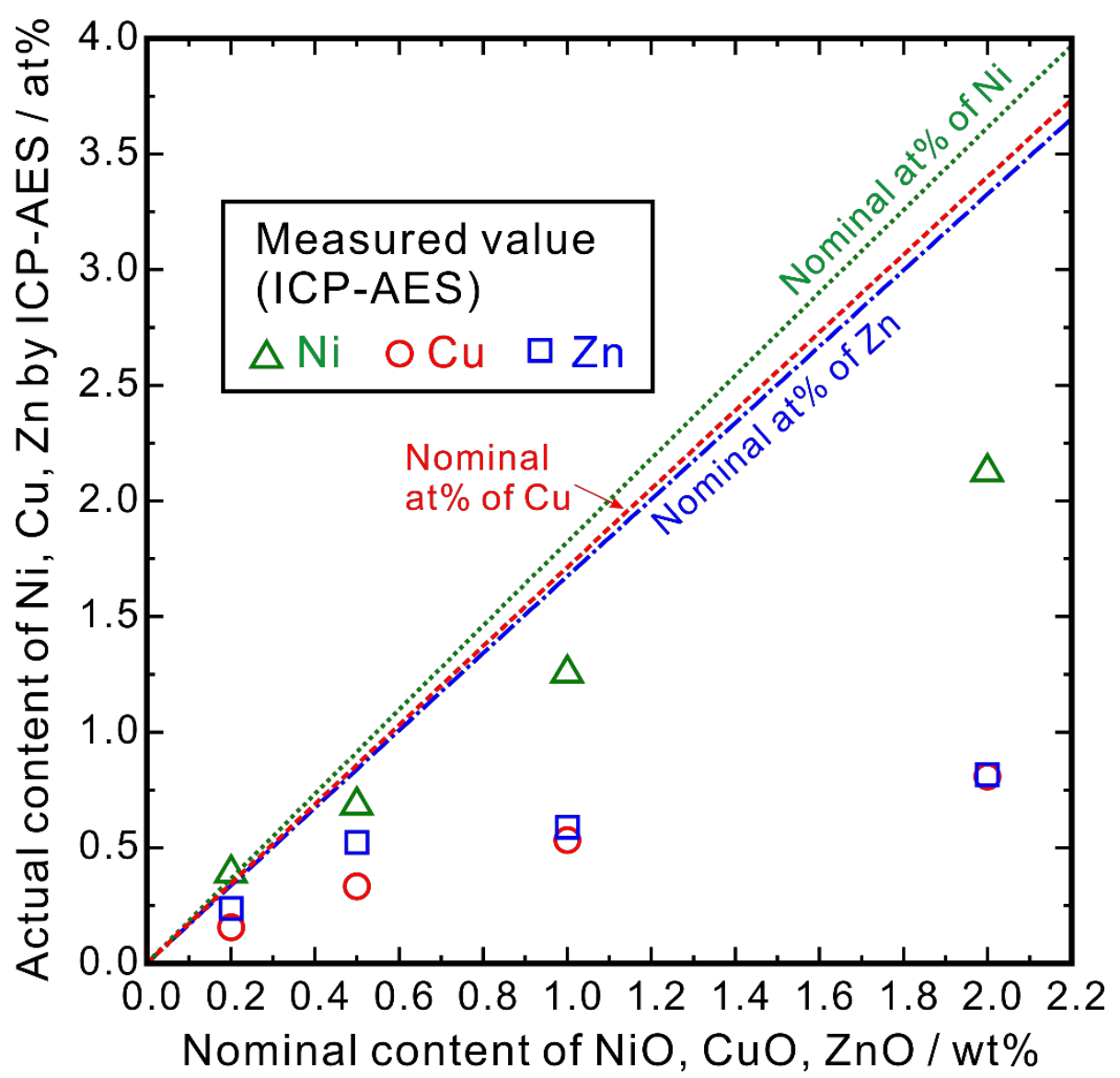

Fig. 2 Actual composition of $\mathrm{Ni}, \mathrm{Cu}, \mathrm{Zn}$ in the as-sintered samples determined by ICP-AES measurements plotted against the nominal content of $\mathrm{NiO}, \mathrm{CuO}, \mathrm{ZnO}$ added into BZY20. The samples were heat-treated at $1500{ }^{\circ} \mathrm{C}$ in $\mathrm{O}_{2}$ for $10 \mathrm{~h}$ for sintering. 
(a) $\mathrm{BZY} 20-\mathrm{NiO}$

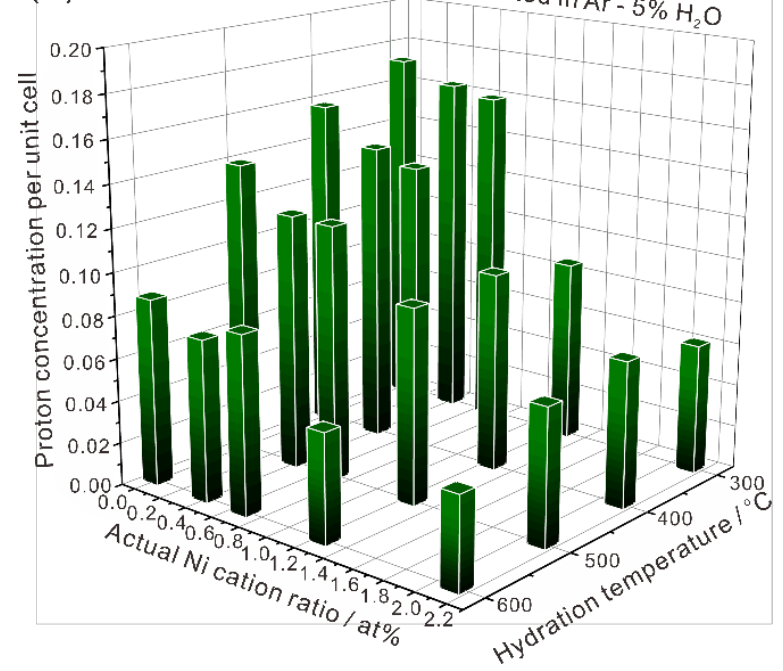

(b) BZY20 - CuO

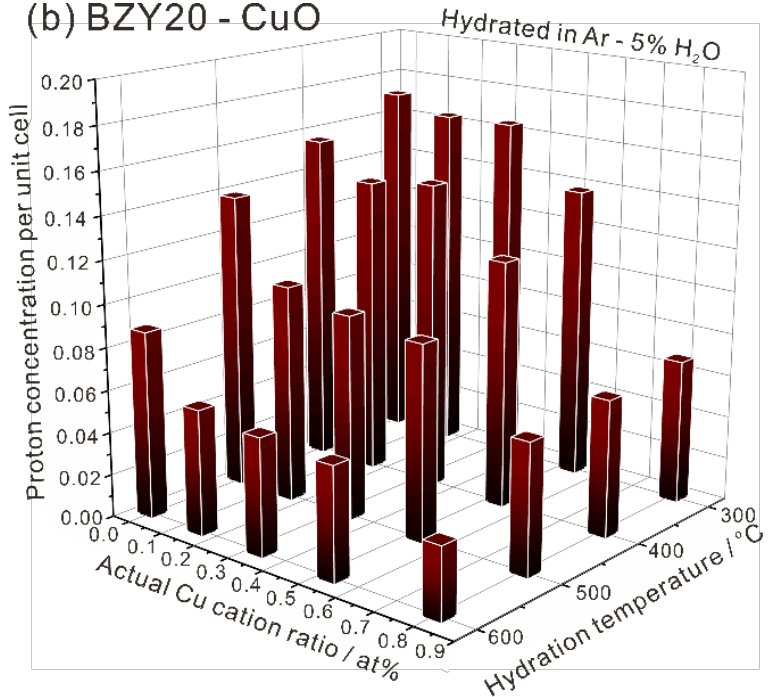

(c) BZY20 - ZnO Hydrated in $\mathrm{Ar}-5 \% \mathrm{HO}$

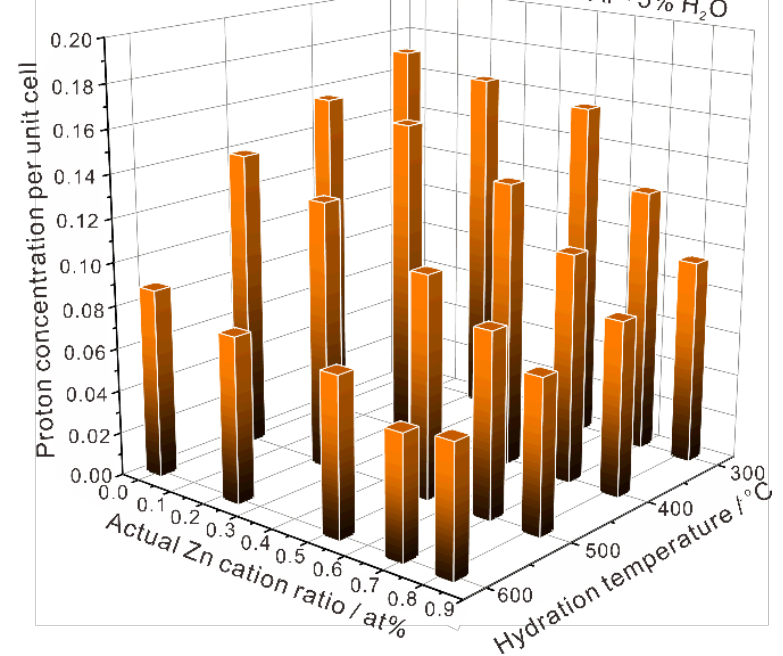

Fig. 3 Proton concentration of BZY20 added with various content of $\mathrm{NiO}$, $\mathrm{CuO}$ or $\mathrm{ZnO}$, plotted against the actual cation ratio of $\mathrm{Ni}$, Cu or $\mathrm{Zn}$ measured by ICP-AES. The samples were sintered at $1500{ }^{\circ} \mathrm{C}$ in oxygen for $10 \mathrm{~h}$, and hydrated in $\mathrm{Ar}-5 \% \mathrm{H}_{2} \mathrm{O}$. The proton concentration was calculated from water content measured by Karl-Fischer titration method. 


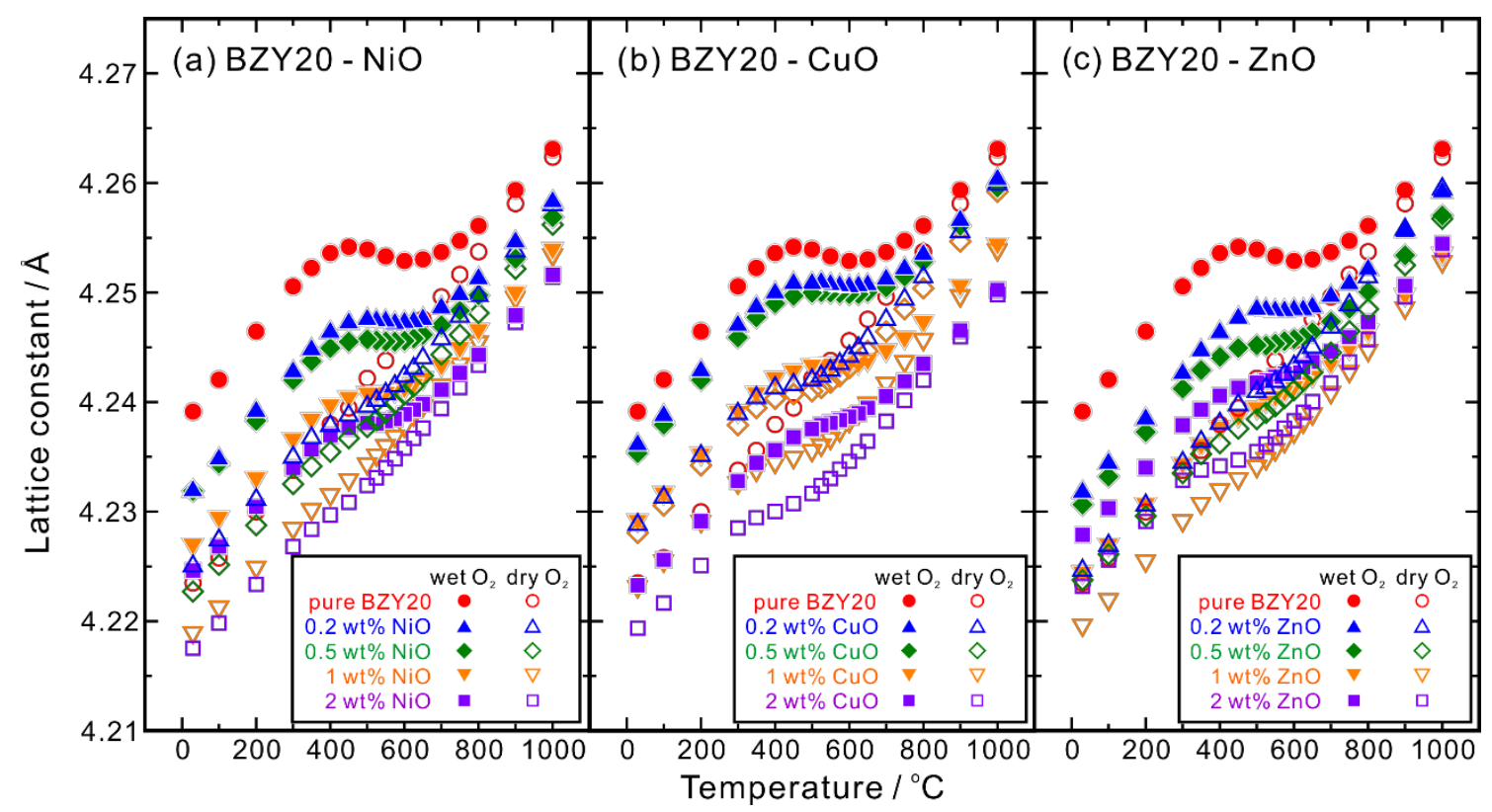

Fig. 4 Temperature dependence of lattice constants of BZY20 added with various content of NiO,

$\mathrm{CuO}$ or $\mathrm{ZnO}$ in dry or wet $\mathrm{O}_{2}\left(p_{\mathrm{H}_{2} \mathrm{O}}=0.031 \mathrm{~atm}\right)$ atmosphere. All the samples were finally heattreatment at $1500{ }^{\circ} \mathrm{C}$ in $\mathrm{O}_{2}$ for $10 \mathrm{~h}$ for sintering. The profile of pure BZY20 [3] is also plotted for comparison. 

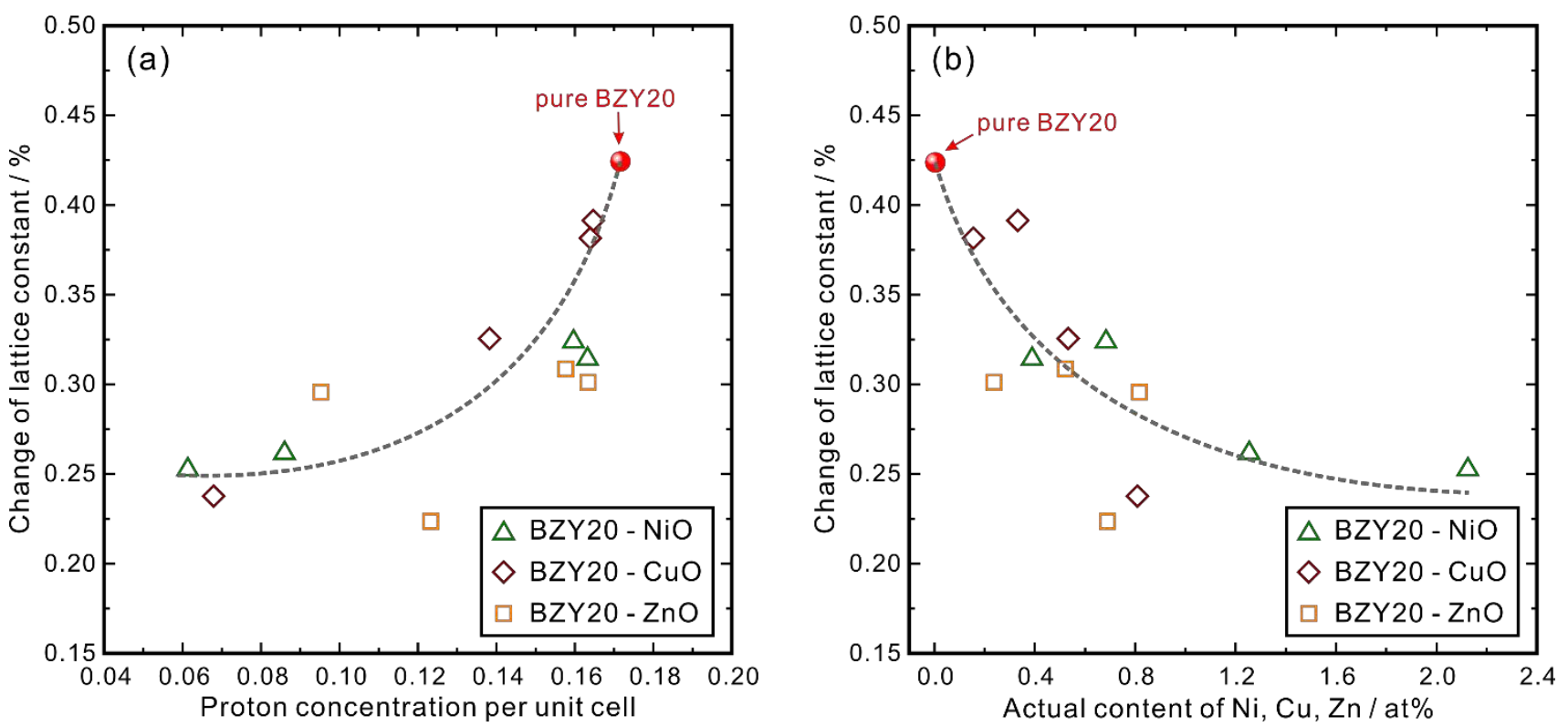

Fig. 5 Change of lattice constant of BZY20 added with various content of $\mathrm{NiO}, \mathrm{CuO}$ or $\mathrm{ZnO}$ due to hydration plotted against (a) proton concentration, and (b) actual cation ratio of $\mathrm{Ni}, \mathrm{Cu}$, Zn measured by ICP-AES. All the samples were prepared by heat-treating at $1500{ }^{\circ} \mathrm{C}$ in $\mathrm{O}_{2}$ for $10 \mathrm{~h}$ for sintering. The data of pure BZY20 which was sintered at $1600{ }^{\circ} \mathrm{C}$ in $\mathrm{O}_{2}$ for $24 \mathrm{~h}$ was also plotted for comparison. 
BZY20 - $0.5 \mathrm{wt} \% \mathrm{NiO}$
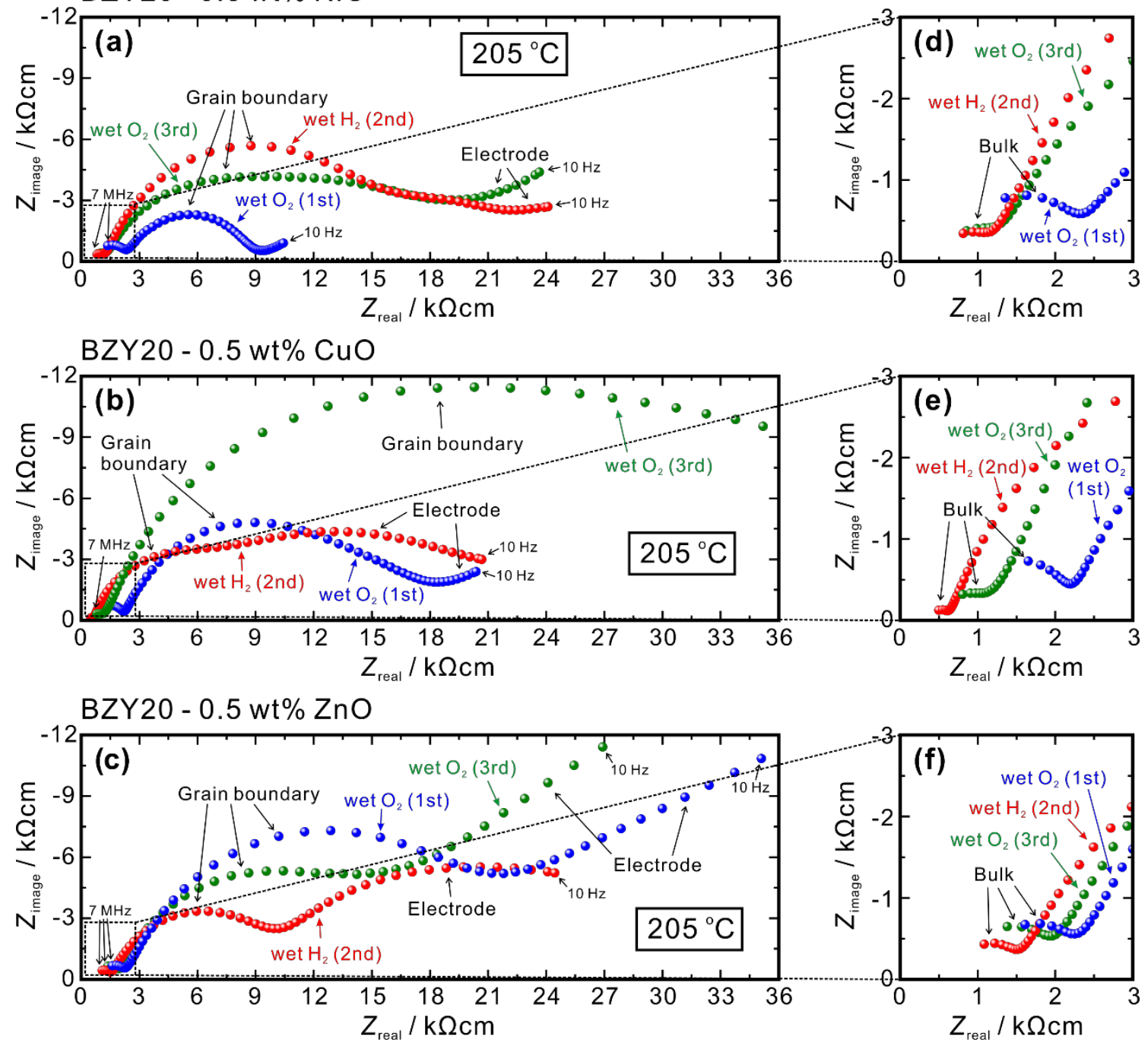

Fig. 6 Impedance spectra of BZY20 added nominally with $0.5 \mathrm{wt} \% \mathrm{NiO}$, $\mathrm{CuO}$, or $\mathrm{ZnO}$ collected at $205{ }^{\circ} \mathrm{C}$ in wet $\mathrm{O}_{2}\left(1^{\text {st }}\right.$ cycle), wet $\mathrm{H}_{2}$ ( $2^{\text {nd }}$ cycle) and wet $\mathrm{O}_{2}$ ( $3^{\text {rd }}$ cycle) in sequence. The partial pressure of water vapor was 0.05 atm. 
Bulk conductivity at $300^{\circ} \mathrm{C}$

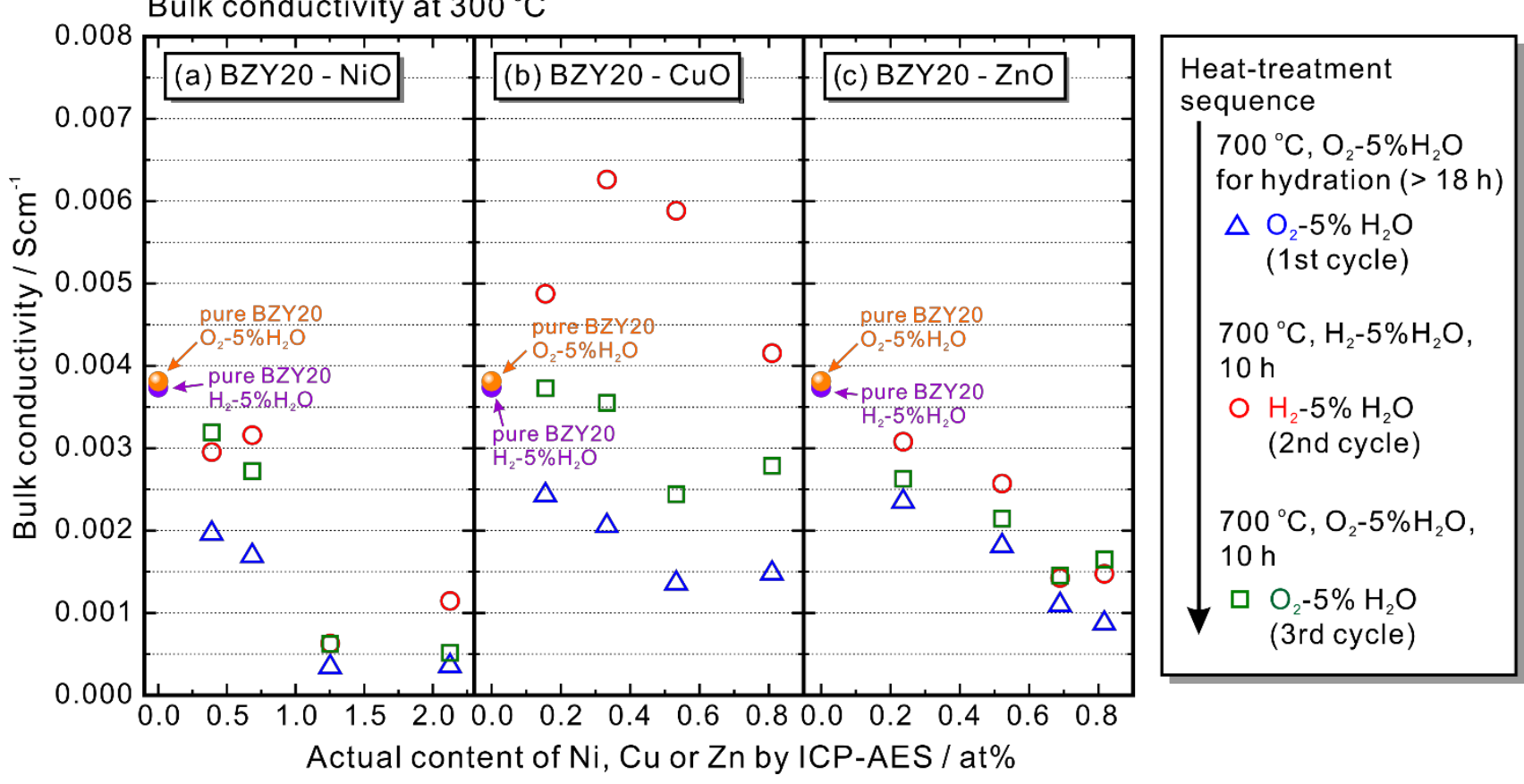

Fig. 7 Bulk (intra-grain) conductivity at $300{ }^{\circ} \mathrm{C}$ of BZY20 added with various content of $\mathrm{NiO}$, $\mathrm{CuO}$ or $\mathrm{ZnO}$ measured in wet $\mathrm{O}_{2}$ ( $1^{\text {st }}$ cycle), wet $\mathrm{H}_{2}$ ( $2^{\text {nd }}$ cycle) and wet $\mathrm{O}_{2}$ ( $3^{\text {rd }}$ cycle) in sequence. The partial pressure of water vapor was 0.05 atm. 


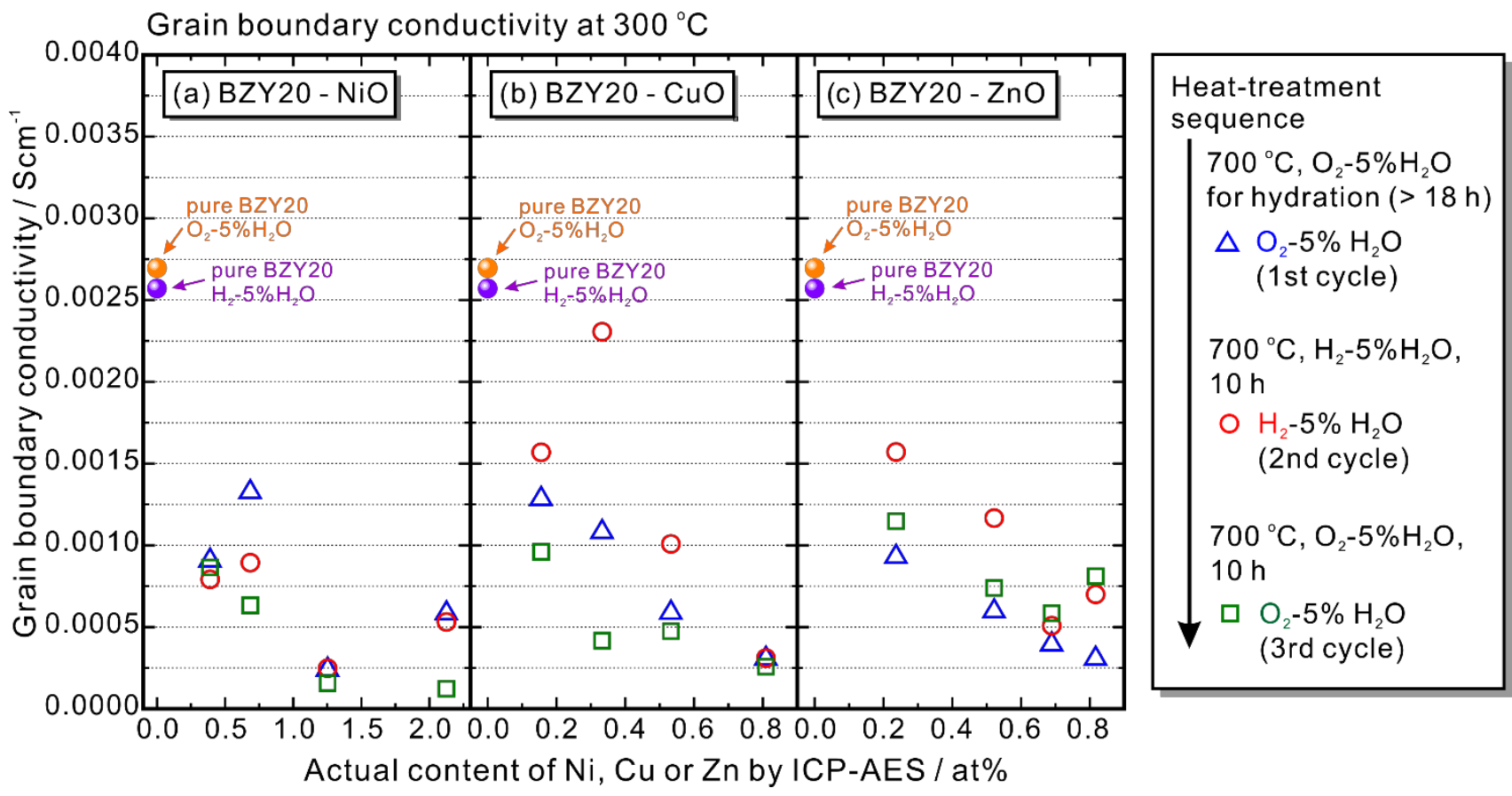

Fig. 8 Grain boundary conductivity at $300{ }^{\circ} \mathrm{C}$ of BZY20 added with various content of $\mathrm{NiO}, \mathrm{CuO}$ or $\mathrm{ZnO}$ measured in wet $\mathrm{O}_{2}\left(1^{\text {st }}\right.$ cycle $)$, wet $\mathrm{H}_{2}\left(2^{\text {nd }}\right.$ cycle $)$ and wet $\mathrm{O}_{2}\left(3^{\text {rd }}\right.$ cycle $)$ in sequence. The partial pressure of water vapor was 0.05 atm. 


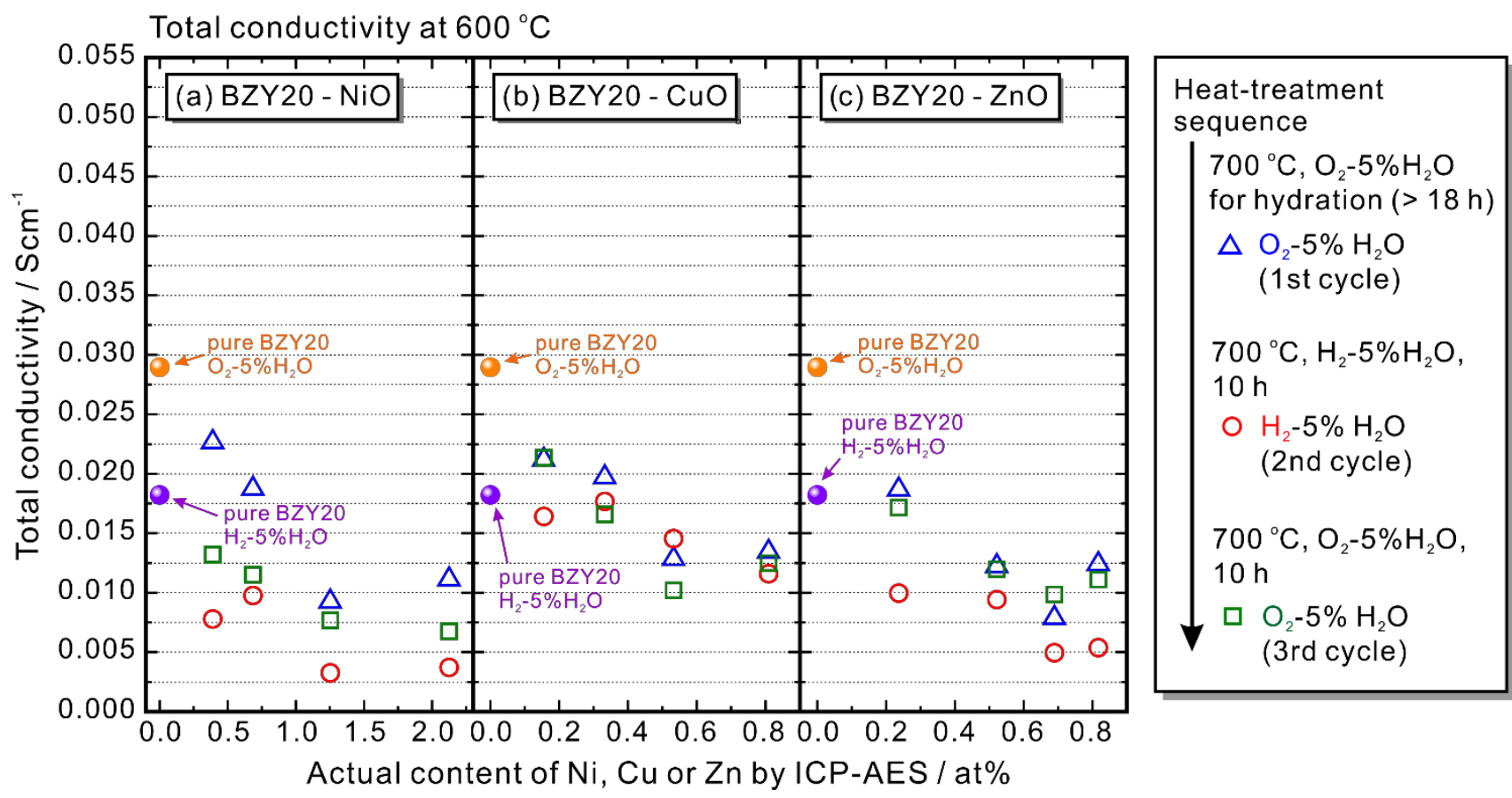

Fig. 9 Total conductivity at $600{ }^{\circ} \mathrm{C}$ of BZY20 added with various content of $\mathrm{NiO}$, $\mathrm{CuO}$ or $\mathrm{ZnO}$ measured in wet $\mathrm{O}_{2}$ ( $1^{\text {st }}$ cycle), wet $\mathrm{H}_{2}$ ( $2^{\text {nd }}$ cycle) and wet $\mathrm{O}_{2}\left(3^{\text {rd }}\right.$ cycle) in sequence. The partial pressure of water vapor was $0.05 \mathrm{~atm}$. 
(a) in wet reducing $\left(\mathrm{H}_{2}\right)$ atmosphere

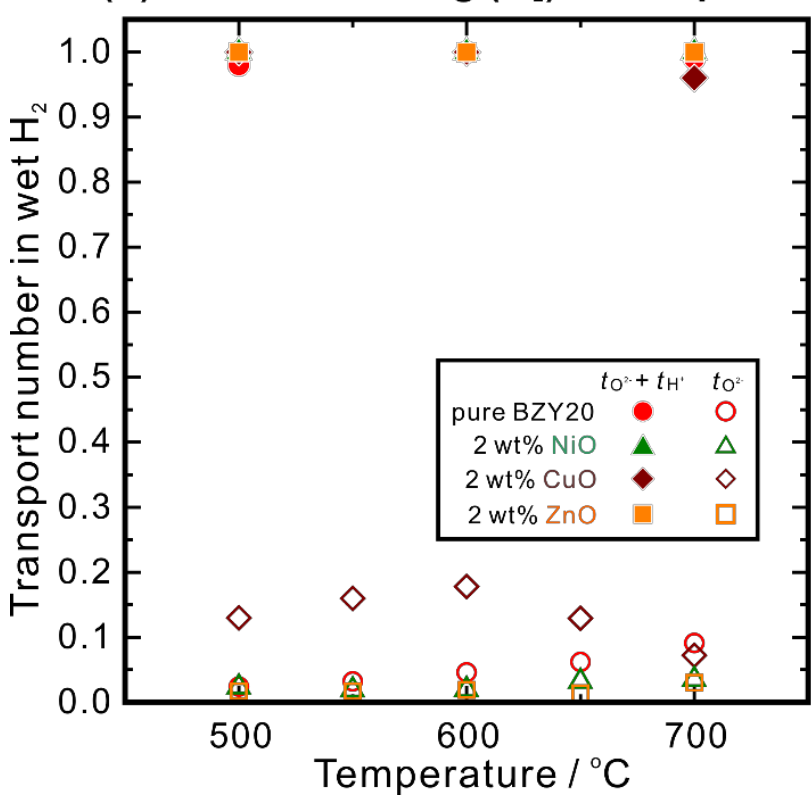

(b) in wet oxidizing $\left(\mathrm{O}_{2}\right)$ atmosphere

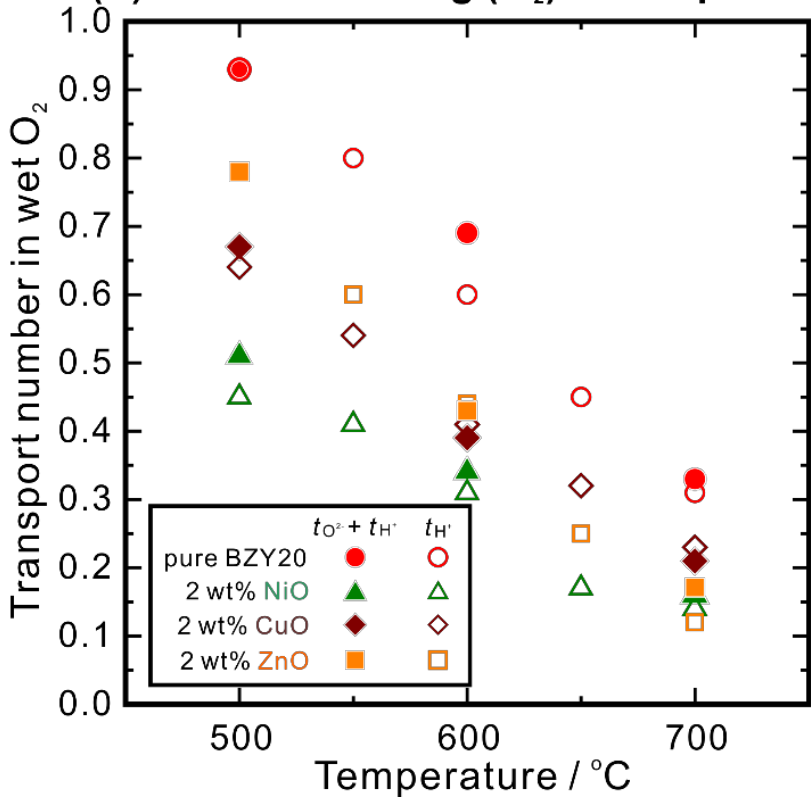

Fig. 10 Transport numbers of ionic conduction in pure BZY20 and those added nominally with 2 wt $\% \mathrm{NiO}, \mathrm{CuO}$ or $\mathrm{NiO}$ determined by the EMF method in (a) wet reducing $\left(\mathrm{H}_{2}\right)$, and (b) wet oxidizing $\left(\mathrm{O}_{2}\right)$ atmosphere. The transport number obtained in wet oxidizing $\left(\mathrm{O}_{2}\right)$ atmosphere were compensated by taking the effect from electrode polarization into consideration. In (a), the solid symbols are overlapped with each other since $t_{\mathrm{O}^{2-}}+t_{\mathrm{H}^{+}}$is very close to unit for all the samples in wet hydrogen. 

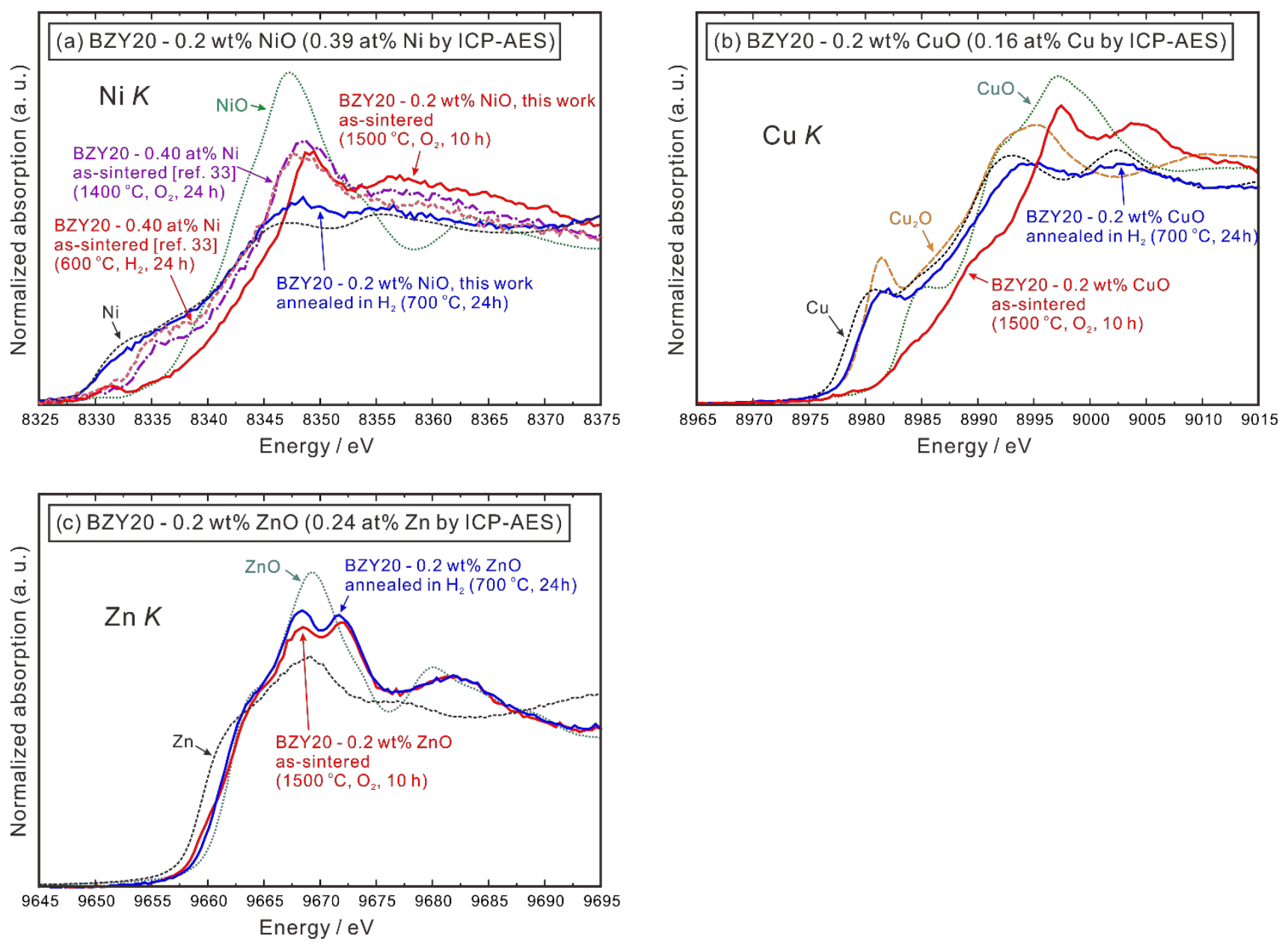

Fig. 11 (a) Ni K-edge XANES spectra of BZY20 - $0.2 \mathrm{wt} \% \mathrm{NiO}$, (b) Cu K-edge XANES spectra of BZY20 - 0.2 wt\% CuO, and (c) Zn K-edge XANES spectra of BZY20 - 0.2 wt\% ZnO collected at 20 $\mathrm{K}$ in a vacuum. All the samples were heat-treated at $1500{ }^{\circ} \mathrm{C}$ in oxygen for $10 \mathrm{~h}$ for sintering, and sequentially annealed in hydrogen at $700{ }^{\circ} \mathrm{C}$ for $24 \mathrm{~h}$. Ni K-edge XANES spectra of BZY20 -0.40 at\% Ni (actual composition by ICP-AES) sintered at $1400{ }^{\circ} \mathrm{C}$ in oxygen for $24 \mathrm{~h}$, and subsequently annealed in $\mathrm{H}_{2}$ for $24 \mathrm{~h}$, which were reported in our previous work [33], was also plotted in (a) for comparison. 
Table 1 Reported performance at $600{ }^{\circ} \mathrm{C}$ of anode-supported PCFCs using BZY-based electrolytes. The thickness of the electrolyte layer was used in calculating the electrolyte conductivity. The performances of cells with the BZY electrolyte layer prepared by PLD [21, 30] were also listed for comparison.

\begin{tabular}{|c|c|c|c|c|c|c|c|c|c|}
\hline \multirow{2}{*}{$\begin{array}{l}\text { Year } \\
\text { for } \\
\text { report }\end{array}$} & \multirow[t]{2}{*}{ Reporters } & \multicolumn{3}{|l|}{ Electrolyte } & \multirow[t]{2}{*}{ Anode } & \multirow[t]{2}{*}{ Cathode } & \multirow{2}{*}{$\begin{array}{l}\text { Co-sintering } \\
\text { temperature / } \\
{ }^{\circ} \mathrm{C}\end{array}$} & \multicolumn{2}{|c|}{ Cell performance } \\
\hline & & Nominal composition & $\begin{array}{l}\text { Thickness } \\
\text { / } \mu \mathrm{m}\end{array}$ & $\begin{array}{l}\text { Conductivity } \\
/ \mathrm{Scm}^{-1}\end{array}$ & & & & $\begin{array}{l}\mathrm{OCV} \\
/ \mathrm{V}\end{array}$ & $\begin{array}{l}\text { Peak } \\
\text { power } \\
\text { density / } \\
\text { mWcm }{ }^{-2}\end{array}$ \\
\hline 2010 & $\begin{array}{l}\text { Sun, et al. } \\
\text { [20] }\end{array}$ & $\mathrm{BaZr}_{0.8} \mathrm{Y}_{0.2} \mathrm{O}_{3-\delta}$ & 20 & $1.4 \times 10^{-3}$ & $\begin{array}{l}\mathrm{BaZr}_{0.1} \mathrm{Ce}_{0.7} \mathrm{Y}_{0.2} \mathrm{O}_{3-\delta} \\
-60 \mathrm{wt} \% \mathrm{NiO}\end{array}$ & $\begin{array}{l}\mathrm{Sm}_{0.5} \mathrm{Sr}_{0.5} \mathrm{CoO}_{3-\delta}-40 \\
\text { wt } \% \mathrm{Ce}_{0.8} \mathrm{Sm}_{0.2} \mathrm{O}_{2-\delta}\end{array}$ & 1400 & 1.014 & 70 \\
\hline 2010 & $\begin{array}{l}\text { Pergolesi, } \\
\text { el al. [21] }\end{array}$ & $\mathrm{BaZr}_{0.8} \mathrm{Y}_{0.2} \mathrm{O}_{3-\delta}$ & 4 & $2.1 \times 10^{-4}$ & $\begin{array}{l}\mathrm{BaZr}_{0.8} \mathrm{Y}_{0.2} \mathrm{O}_{3-\delta}-26 \\
\text { wt\% } \mathrm{NiO}\end{array}$ & $\begin{array}{l}\mathrm{BaCe}_{0.9} \mathrm{Yb}_{0.1} \mathrm{O}_{3-\delta}-50 \\
\mathrm{wt} \% \\
\mathrm{La}_{0.6} \mathrm{Sr}_{0.4} \mathrm{Co}_{0.2} \mathrm{Fe}_{0.8} \mathrm{O}_{3-\delta}\end{array}$ & By PLD & 0.99 & 110 \\
\hline 2011 & $\begin{array}{l}\text { Fabbri, et } \\
\text { al. [22] }\end{array}$ & $\mathrm{BaZr}_{0.7} \mathrm{Pr}_{0.1} \mathrm{Y}_{0.2} \mathrm{O}_{3-\delta}$ & 20 & $1.5 \times 10^{-3}$ & $\begin{array}{l}\mathrm{BaZr}_{0.8} \mathrm{Y}_{0.2} \mathrm{O}_{3-\delta}-70 \\
\text { wt\% NiO }\end{array}$ & $\begin{array}{l}\mathrm{BaZr}_{0.7} \mathrm{Pr}_{0.1} \mathrm{Y}_{0.2} \mathrm{O}_{3-\delta}-50 \\
\text { wt\% } \\
\mathrm{La}_{0.6} \mathrm{Sr}_{0.4} \mathrm{Co}_{0.2} \mathrm{Fe}_{0.8} \mathrm{O}_{3-\delta}\end{array}$ & 1500 & 0.93 & 81 \\
\hline 2011 & $\begin{array}{l}\mathrm{Bi} \text {, et al. } \\
\text { [23] }\end{array}$ & $\mathrm{BaZr}_{0.8} \mathrm{Y}_{0.2} \mathrm{O}_{3-\delta}$ & 30 & $2.7 \times 10^{-3}$ & $\begin{array}{l}\mathrm{BaZr}_{0.8} \mathrm{Y}_{0.2} \mathrm{O}_{3-\delta}-50 \\
\mathrm{wt} \% \mathrm{NiO}\end{array}$ & $\begin{array}{l}\mathrm{BaZr}_{0.7} \mathrm{Pr}_{0.1} \mathrm{Y}_{0.2} \mathrm{O}_{3-\delta}-50 \\
\mathrm{wt} \% \\
\mathrm{La}_{0.6} \mathrm{Sr}_{0.4} \mathrm{Co}_{0.2} \mathrm{Fe}_{0.8} \mathrm{O}_{3-\delta}\end{array}$ & 1400 & 0.95 & 51 \\
\hline 2012 & $\begin{array}{l}\text { Sun, et al. } \\
\text { [24] }\end{array}$ & $\mathrm{BaZr}_{0.8} \mathrm{Y}_{0.2} \mathrm{O}_{3-\delta}-\mathrm{CaO}$ & 25 & $1.7 \times 10^{-3}$ & $\begin{array}{l}\mathrm{BaZr}_{0.8} \mathrm{Y}_{0.2} \mathrm{O}_{3-\delta}-60 \\
\mathrm{wt} \% \mathrm{NiO}\end{array}$ & $\begin{array}{l}\mathrm{BaZr}_{0.8} \mathrm{Y}_{0.2} \mathrm{O}_{3-\delta}-61 \\
\text { wt\% } \\
\mathrm{La}_{0.6} \mathrm{Sr}_{0.4} \mathrm{Co}_{0.2} \mathrm{Fe}_{0.8} \mathrm{O}_{3-\delta}\end{array}$ & 1400 & 0.96 & 72 \\
\hline
\end{tabular}




\begin{tabular}{|c|c|c|c|c|c|c|c|c|c|}
\hline 2012 & $\begin{array}{l}\text { Xiao, et al. } \\
{[25]}\end{array}$ & $\mathrm{BaZr}_{0.8} \mathrm{Y}_{0.2} \mathrm{O}_{3-\delta}$ & 25 & $7.7 \times 10^{-4}$ & $\begin{array}{l}\mathrm{BaZr}_{0.1} \mathrm{Ce}_{0.7} \mathrm{Y}_{0.2} \mathrm{O}_{3-\delta}- \\
40 \mathrm{wt} \% \mathrm{NiO}\end{array}$ & $\begin{array}{l}\mathrm{Sm}_{0.5} \mathrm{Sr}_{0.5} \mathrm{CoO}_{3-\delta}-30 \\
\text { wt\% } \mathrm{Ce}_{0.8} \mathrm{Sm}_{0.2} \mathrm{O}_{2-\delta}\end{array}$ & 1450 & 0.97 & 55 \\
\hline 2012 & $\begin{array}{l}\text { Luisetto, et } \\
\text { al. [26] }\end{array}$ & $\mathrm{BaZr}_{0.8} \mathrm{Y}_{0.16} \mathrm{Zn}_{0.04} \mathrm{O}_{3-\delta}$ & 20 & $1.7 \times 10^{-3}$ & $\begin{array}{l}\mathrm{BaZr}_{0.8} \mathrm{Y}_{0.2} \mathrm{O}_{3-\delta}-60 \\
\mathrm{wt} \% \mathrm{NiO}\end{array}$ & $\mathrm{Pt}$ & 1450 & 0.93 & 47 \\
\hline 2012 & $\begin{array}{l}\text { Liu, et al. } \\
\text { [27] }\end{array}$ & $\mathrm{BaZr}_{0.7} \mathrm{Nd}_{0.1} \mathrm{Y}_{0.2} \mathrm{O}_{3-\delta}$ & 30 & $2.0 \times 10^{-3}$ & $\begin{array}{l}\mathrm{BaZr}_{0.7} \mathrm{Nd}_{0.1} \mathrm{Y}_{0.2} \mathrm{O}_{3-\delta}- \\
50 \mathrm{wt} \% \mathrm{NiO}\end{array}$ & $\mathrm{Ba}_{0.5} \mathrm{Sr}_{0.5} \mathrm{Co}_{0.8} \mathrm{Fe}_{0.2} \mathrm{O}_{3-\delta}$ & 1450 & 0.99 & 105 \\
\hline 2014 & $\begin{array}{l}\text { Sun, et al. } \\
{[28]}\end{array}$ & $\mathrm{BaZr}_{0.8} \mathrm{Y}_{0.15} \mathrm{In}_{0.05} \mathrm{O}_{3-\delta}$ & 12 & $2.4 \times 10^{-3}$ & $\begin{array}{l}\mathrm{BaZr}_{0.8} \mathrm{Y}_{0.15} \mathrm{In}_{0.05} \mathrm{O}_{3-\delta}- \\
65 \mathrm{wt} \% \mathrm{NiO}\end{array}$ & $\begin{array}{l}\mathrm{Sm}_{0.5} \mathrm{Sr}_{0.5} \mathrm{CoO}_{3-\delta}-40 \\
\text { wt\% } \mathrm{Ce}_{0.8} \mathrm{Sm}_{0.2} \mathrm{O}_{2-\delta}\end{array}$ & 1400 & 0.99 & 81 \\
\hline 2015 & $\begin{array}{l}\text { Shafi, et al. } \\
\text { [29] }\end{array}$ & $\mathrm{BaZr}_{0.76} \mathrm{Y}_{0.2} \mathrm{Ni}_{0.04} \mathrm{O}_{3-\delta}$ & 12 & $2.1 \times 10^{-3}$ & $\begin{array}{l}\mathrm{BaZr}_{0.8} \mathrm{Y}_{0.2} \mathrm{O}_{3-\delta}-60 \\
\text { wt\% } \mathrm{NiO}\end{array}$ & $\begin{array}{l}\mathrm{BaZr}_{0.8} \mathrm{Y}_{0.2} \mathrm{O}_{3-\delta}-70 \\
\mathrm{wt} \% \mathrm{PrBaCo}_{2} \mathrm{O}_{5+\delta}\end{array}$ & 1450 & 1.01 & 240 \\
\hline 2015 & $\begin{array}{l}\text { Duan, et } \\
\text { al. [19] }\end{array}$ & $\begin{array}{l}\mathrm{BaZr}_{0.8} \mathrm{Y}_{0.2} \mathrm{O}_{3-\delta}-1.0 \\
\mathrm{wt} \% \mathrm{NiO}\end{array}$ & 25 & $\sim 0.9 \times 10^{-3}$ & $\begin{array}{l}\mathrm{BaZr}_{0.8} \mathrm{Y}_{0.2} \mathrm{O}_{3-\delta}-55 \\
\text { wt\% } \mathrm{NiO}\end{array}$ & $\mathrm{BaCo}_{0.4} \mathrm{Fe}_{0.4} \mathrm{Zr}_{0.1} \mathrm{Y}_{0.1} \mathrm{O}_{3-\delta}$ & 1450 & 0.99 & 420 \\
\hline 2015 & $\begin{array}{l}\text { Duan, et } \\
\text { al. [19] }\end{array}$ & $\begin{array}{l}\mathrm{BaZr}_{0.8} \mathrm{Y}_{0.2} \mathrm{O}_{3-\delta}-1.4 \\
\mathrm{wt} \% \mathrm{CuO}\end{array}$ & 25 & unknown & $\begin{array}{l}\mathrm{BaZr}_{0.8} \mathrm{Y}_{0.2} \mathrm{O}_{3-\delta}-55 \\
\text { wt\% } \mathrm{NiO}\end{array}$ & $\mathrm{BaCo}_{0.4} \mathrm{Fe}_{0.4} \mathrm{Zr}_{0.1} \mathrm{Y}_{0.1} \mathrm{O}_{3-\delta}$ & 1450 & 0.99 & 470 \\
\hline 2017 & $\begin{array}{l}\text { Bae, et al. } \\
{[30]}\end{array}$ & $\mathrm{BaZr}_{0.85} \mathrm{Y}_{0.15} \mathrm{O}_{3-\delta}$ & 2.5 & $2.78 \times 10^{-3}$ & $\begin{array}{l}\mathrm{BaZr}_{0.85} \mathrm{Y}_{0.15} \mathrm{O}_{3-\delta}-56 \\
\mathrm{wt} \% \mathrm{NiO}\end{array}$ & $\mathrm{La}_{0.6} \mathrm{Sr}_{0.4} \mathrm{CoO}_{3-\delta}$ & By PLD & 1.0 & 740 \\
\hline 2017 & $\begin{array}{l}\mathrm{Bi}, \text { et al. } \\
{[31]}\end{array}$ & $\mathrm{BaZr}_{0.8} \mathrm{Y}_{0.2} \mathrm{O}_{3-\delta}$ & 20 & $4.5 \times 10^{-3}$ & $\begin{array}{l}\mathrm{BaZr}_{0.76} \mathrm{Y}_{0.2} \mathrm{Ni}_{0.04} \mathrm{O}_{3-\delta}- \\
60 \mathrm{wt} \% \mathrm{NiO}\end{array}$ & $\begin{array}{l}\mathrm{BaZr}_{0.8} \mathrm{Y}_{0.2} \mathrm{O}_{3-\delta}-50 \\
\text { wt } \% \mathrm{PrBaCo}_{2} \mathrm{O}_{5+\delta}\end{array}$ & 1400 & 0.99 & 267 \\
\hline 2017 & Dai [32] & $\mathrm{BaZr}_{0.75} \mathrm{Y}_{0.2} \mathrm{Pr}_{0.05} \mathrm{O}_{3-\delta}$ & 20 & $2 \times 10^{-3}$ & $\begin{array}{l}\mathrm{BaZr}_{0.75} \mathrm{Y}_{0.2} \mathrm{Pr}_{0.05} \mathrm{O}_{3-\delta}- \\
60 \mathrm{wt} \% \mathrm{NiO}\end{array}$ & $\begin{array}{l}\mathrm{BaZr}_{0.75} \mathrm{Y}_{0.2} \mathrm{Pr}_{0.05} \mathrm{O}_{3-\delta}- \\
\mathrm{La}_{0.6} \mathrm{Sr}_{0.4} \mathrm{Co}_{0.2} \mathrm{Fe}_{0.8} \mathrm{O}_{3-\delta}\end{array}$ & 1400 & 0.93 & 124 \\
\hline
\end{tabular}


Table 2 Average and local concentration of Ni, Cu, or Zn in BZY20 added nominally with 2 wt\% $\mathrm{NiO}, \mathrm{CuO}$, or $\mathrm{ZnO}$, which were heat-treated at $1500{ }^{\circ} \mathrm{C}$ in oxygen for $10 \mathrm{~h}$, and sequentially annealed in hydrogen for $48 \mathrm{~h}$. The average concentration is determined by ICP-AES measurement. The local concentration at intra-grain and grain boundary is determined by STEM-EDS point analysis.

\begin{tabular}{|c|c|c|c|c|c|}
\hline \multirow{3}{*}{$\begin{array}{l}\text { Nominal } \\
\text { composition }\end{array}$} & \multicolumn{5}{|c|}{ Cation ratio of $\mathrm{Ni}, \mathrm{Cu}$ or $\mathrm{Zn}$ in relevant sample / at\% } \\
\hline & \multicolumn{3}{|c|}{ As-sintered $\left(1500{ }^{\circ} \mathrm{C}, \mathrm{O}_{2}, 10 \mathrm{~h}\right)$} & \multicolumn{2}{|c|}{$\begin{array}{l}\text { Annealed in } \mathrm{H}_{2}(700 \\
\left.{ }^{\circ} \mathrm{C}, 48 \mathrm{~h}\right)\end{array}$} \\
\hline & $\begin{array}{l}\text { Average } \\
\text { concentration }\end{array}$ & Intra-grain & $\begin{array}{l}\text { Grain } \\
\text { boundary }\end{array}$ & $\begin{array}{l}\text { Intra- } \\
\text { grain }\end{array}$ & $\begin{array}{l}\text { Grain } \\
\text { boundary }\end{array}$ \\
\hline $\begin{array}{l}\mathrm{BZY20}-2 \quad \text { wt } \% \\
\mathrm{NiO}\end{array}$ & 2.13 & 1.93 & 2.50 & 1.92 & 2.34 \\
\hline $\begin{array}{l}\mathrm{BZY20}-2 \text { wt } \% \\
\mathrm{CuO}\end{array}$ & 0.81 & 0.48 & 2.03 & 0.24 & 0.38 \\
\hline $\begin{array}{l}\mathrm{BZY} 20-2 \quad \mathrm{wt} \% \\
\mathrm{ZnO}\end{array}$ & 0.82 & 0.78 & 0.99 & 0.82 & 1.07 \\
\hline
\end{tabular}

